\title{
استخلاف الإنسان في الأرض بوصفه مقصداً عاماً \\ للقرآن والشريعة والحضارة
}

\section{* عبد السلام محمد الأحمر}

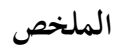

يحاول البحثث التوصل إلى اقتراح مقصد عام مؤطر للميع المقاصد القرآنية، وقادر على بتلية نسقية الخطاب

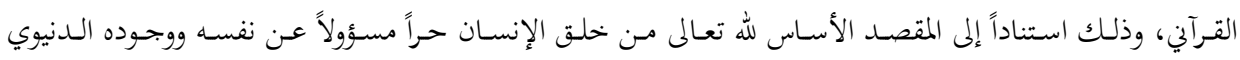

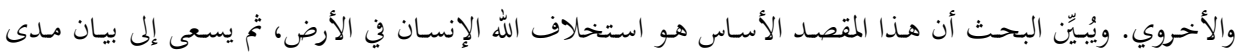

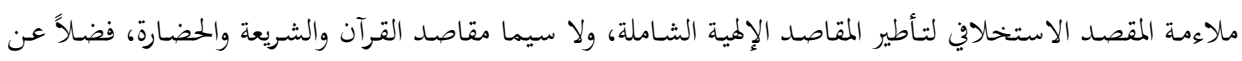

إبراز مدى قدرة الاستخلاف على استيعاب مختلف الاتجاهات الفكرية الإنسانية، وتحفيز الإنحاز العمراني الإسلامي.

الكلمـات المفتاحيـة: المقصد العام الموحسد، الاستخلاف الإيماني، الاستخلاف الوضعي، الخليفة عن الله في
\end{abstract}

الأرض، العمران الإسلامي.

\section{Vicegerency of Man on Earth as a General Intent (Maqsid) Prescribed in the Qur'an and Sharia, and Required for Civilization \\ Abdussalam Al-Ahmar}

Abstract

This paper tries to identify a general intent that encompasses all the Qur'anic intents, and demonstrates a systematic discourse of the Gracious Qur'an. This attempt is based on what we think Allah's purpose of creating a free and responsible Man in his existence on earth and the hereafter.

The paper shows that this general intent is the Vicegerency of Man on earth, and that this intent is a frame of reference to all intents of the Gracious Qur'an, the Shari'a and civilization. Furthermore the paper shows that the concept of Vicegerency would highlight the extent to which it accommodates different human intellectual trends, and stimulates Islamic civilizational accomplishments.

Keywords: Unifying general intent, Faith based vicegerency of Man, Positivistbased vicegerency, Umran (Islamic civilization).

$$
\begin{aligned}
& \text { * ماجستير في الفكر والحضارة من جامعة محمد الخامس في الرباط، والثهادة العليا للدراسات الإسلامية من مؤسسة }
\end{aligned}
$$

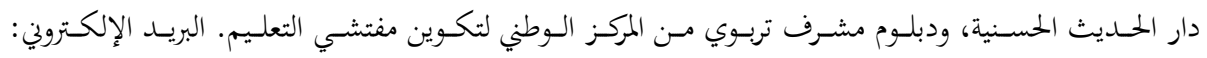

$$
\begin{aligned}
& \text { elahmerab@gmail.com }
\end{aligned}
$$

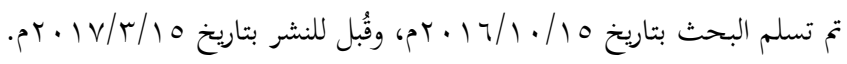


مقدمة:

يهدف البحث إلى إبراز إمكانية الانطلاق في دراسة المقاصد الإسلامية، من مهمة استخلاف الإنسان في الأرض، بوصفه المقصد الأساس لله من خلق الإنسان القادر على اللى

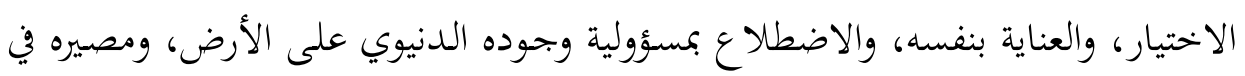

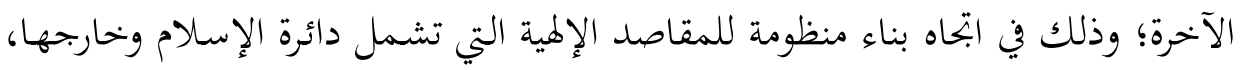
والتي تملك القدرة على استيعاب مختلف الابحاهات الفكرية والحضارية الإنسانية.

ويقوم البحثث على مفهوم راجح للاستخلاف، ويعتمد منهجية قائمة على التتبع والاستقراء للنصوص والمقاصد الشرعية؛ لإثبات مدى استيعاب مقصد الاستخلاف لغيره

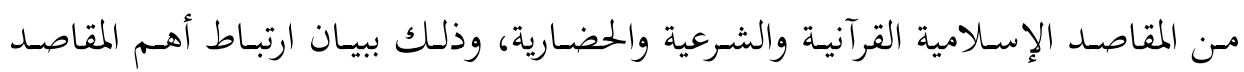
العامة في هذه البحالات بمقصد الاستخلاف الإسية العراسه والترعيه

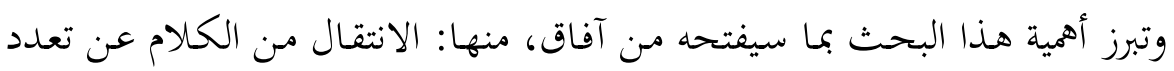

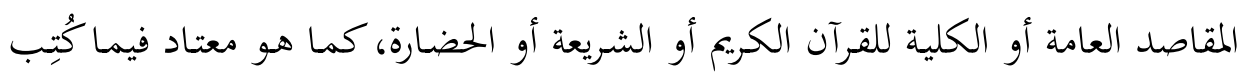

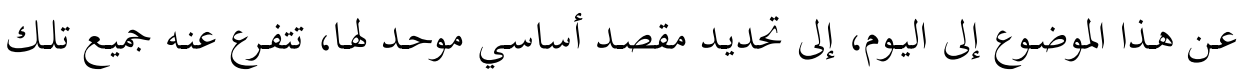

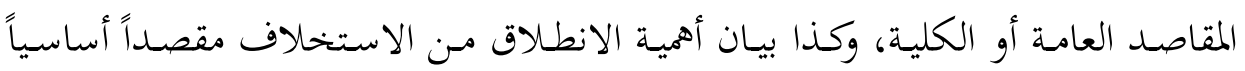

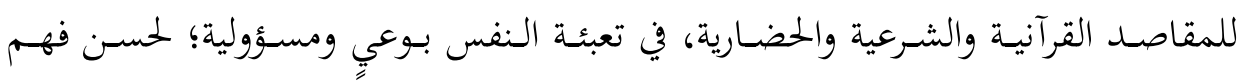

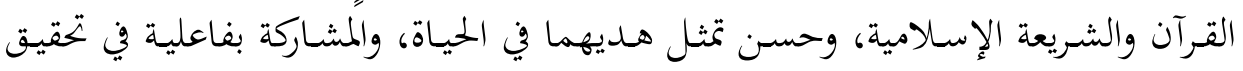

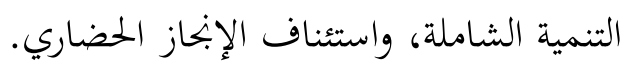

وكـان الباعـث على اقتحـام هـذا الموضـوع أن غالـب الاجتهـادات المقدمـة في بيـان

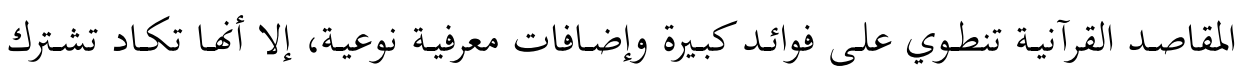

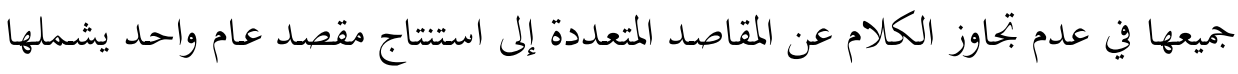
كلها.

وأمَّا التي تحدثت منها عن مقصد واحد عام في موضع فقد جاءت بمقصد أو اثنين

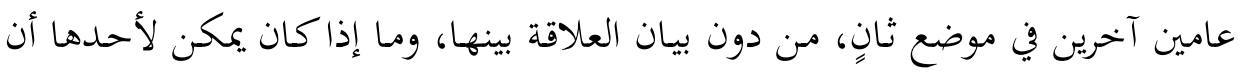
يستوعب الآخرين. 


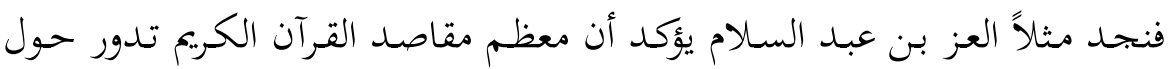

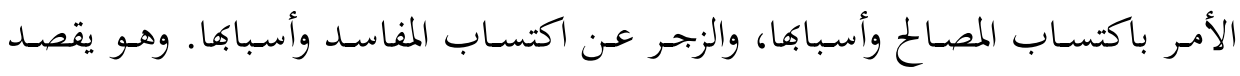

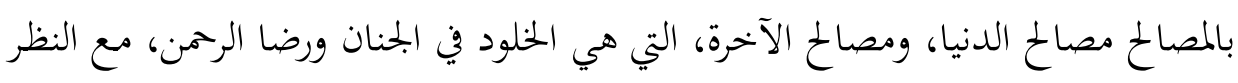

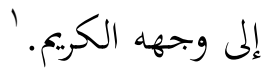

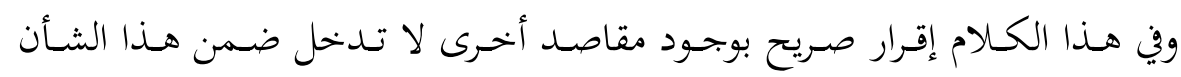

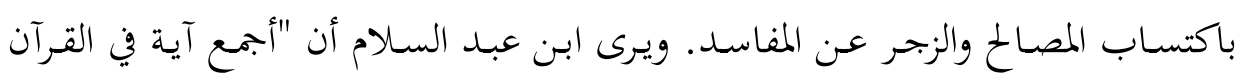

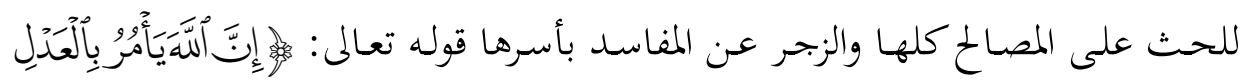

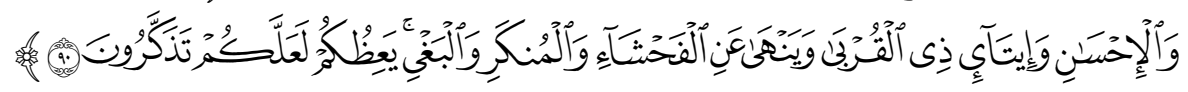

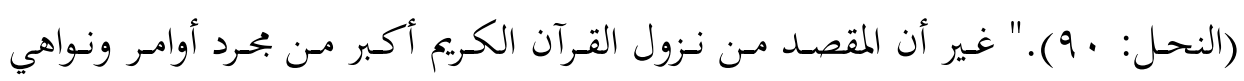

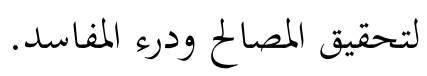

وفي توجُهه آخر نخو تلمُّس نظرة شاملة لمضمون القرآن الكريم، أو صياغة مقصد عام

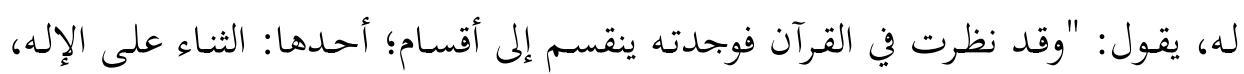

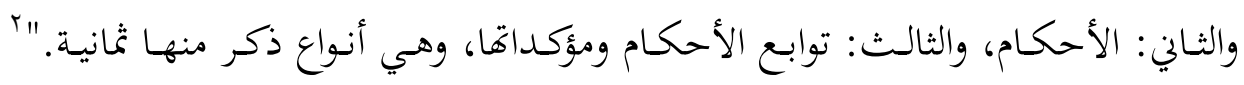
فهذه الأقسام الثلاثة قد تفضي إلى صياغة مقصد عام للقرآن الكريع، لكنها أيضاً تمثل الكابل

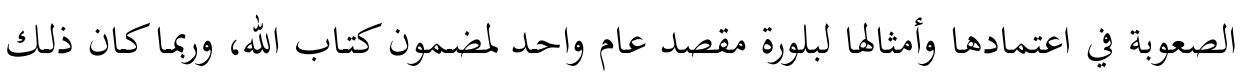
هو ما يصرف عن التفكير في إرجاعها لمقصد واحد وموحد.

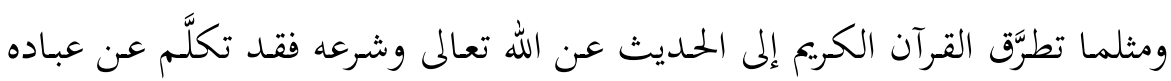

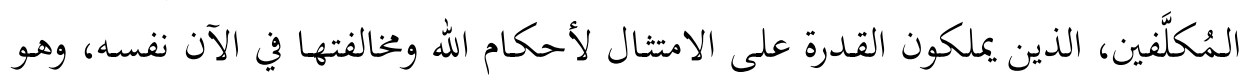
ما يمثل الحكمة السابقة المهيمنة على كل المقاصد.

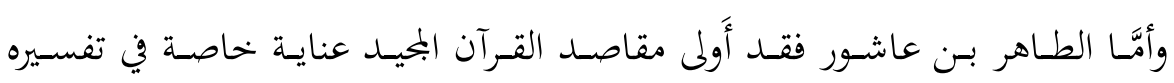

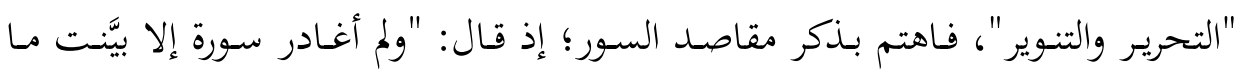

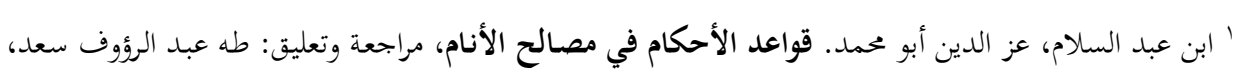

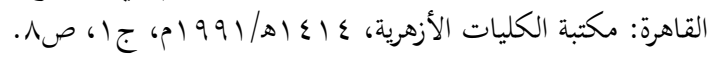

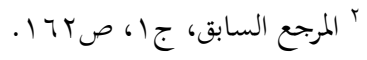




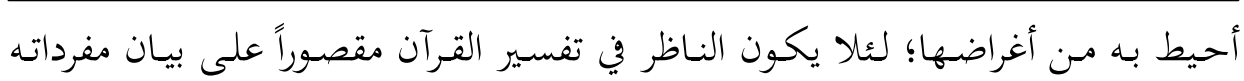

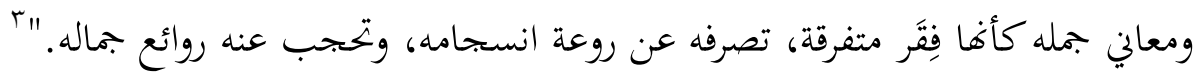

وقـدَّم ابـن عاشـور تصوره للمقصد العـام للقرآن، فحصـره في إصـالح الإنسـان فرداً

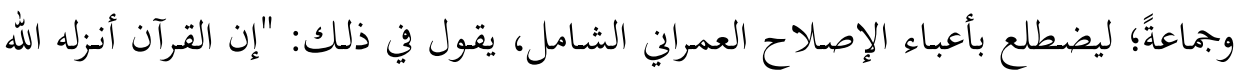

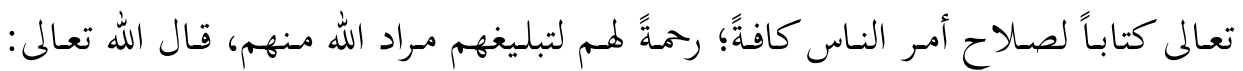

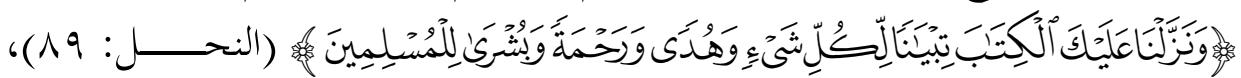

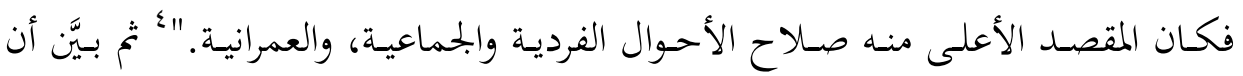

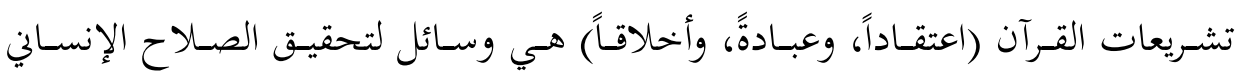
الضروري للصلاح العمراني.

ولكن الصلاح الإنساني الذي قصده القرآن الكريم ودعا إليه لا يتحقق في الواقع إلا

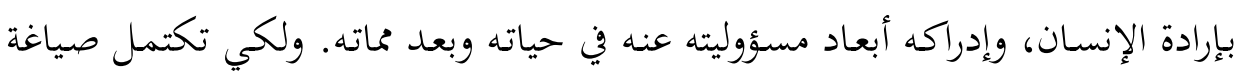

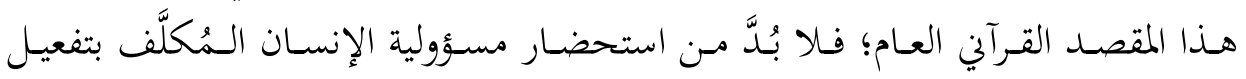
محتوى القرآن على مستوى النفس والواقع. وهكذا ظل حديث علمائنا الأولين والآخرين عن مقاصد القرآن على هذا المنوال مقتصراً على التوسع في تعدادها، وحتى لو راموا حصرها في مقاصد عامة محددة ما أبانوا إمكانية اعتمادها في صياغة منظومة مقاصدية متماسكة.

وقد حـاول طه جـابر العلواني حصرها في خمسـة مقاصد، هي: التوحيد، والتزكيـة،

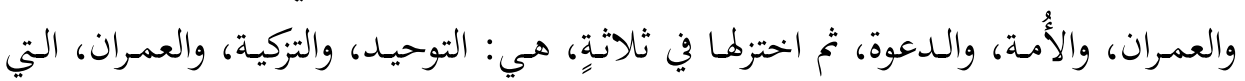
أرى أغها قد تعد مقاصد فروعية كبرى لمقصد واحد،، هو مقصد استخلاف الإنسان على والى الأرض، الذي يشملها كلها، ويؤطرها بصورة واضحة.

وأمَّا الدراسات والأبحاث المعاصرة التي تُقدَّم في ملتقيات علمية تتناول مقاصد القرآن الكريم، فإها تختص غالباً بإبراز جوانب من مقاصد القرآن الجزئية، مثل: مقصد العدل، r ابن عاشور، محمد الطاهر. تحرير المعنى السديد وتنوير العقل الجديد من تفسير الكتاب المجيد، تونس: الدار

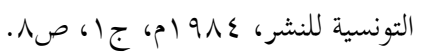

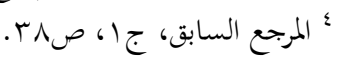


والرحمة، والأمن.... ونادراً ما تتطرَّق إلى المقاصد الكلية، أو تقوم بذلك من دون الإشارة إلى مقصدها الشامل المؤطر لدراستها. وقد تتجه بعض الأبحاث إلى تأكيد أهمية الانتقال

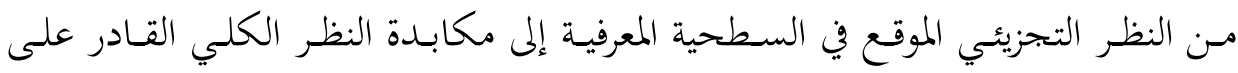

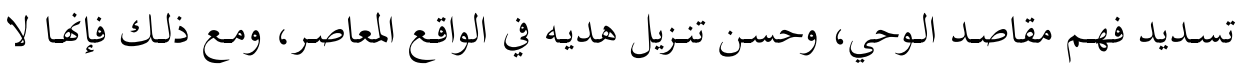

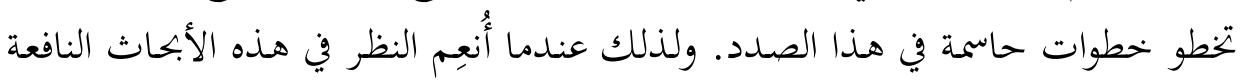

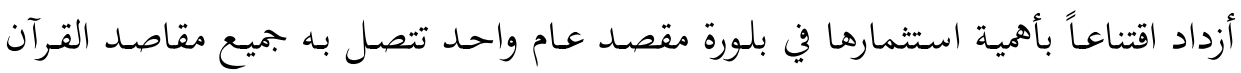
والشريعة والحضارة.

أولاً: المفهـوم الراجح للاسـتخلاف ومسـوغات اختيـاره مقصـداً أساسياً للمقاصـد الإسلامية والإنسانية

\section{1 المفهوم الراجح لاستخلاف الإنسان في الأرض:}

\section{أ. تفسيرات العلماء السابقين لمعنى الاستخلاف:•}

ابته تفسير جمهور العلماء في تحديد معنى استخلاف الإنسان إلى أن بحيئه كان بعد

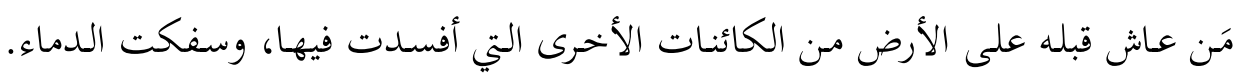

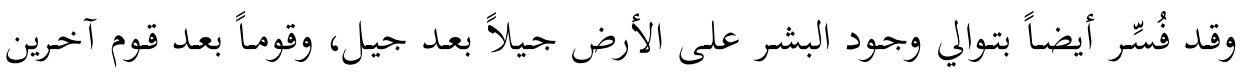

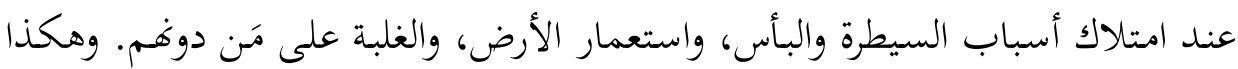
أورد المفسرون لمعنى "خليفة" معنيين:

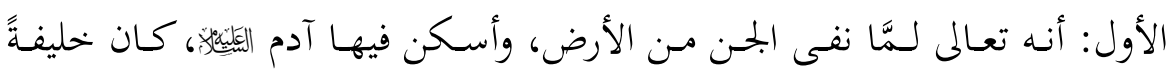
لأولئك الجن الذين تقدَّموه.

الثاني: إنما سمَّاه الله خليفةً؛ لأنه يخلف الله في الحكم بين المُكلَّفين من خلقه، وهو

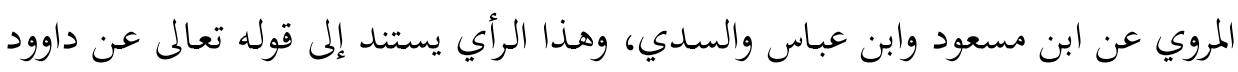

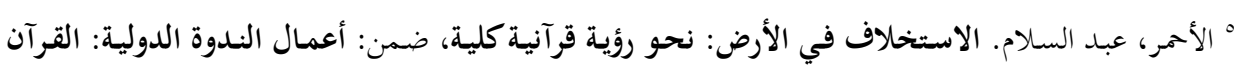

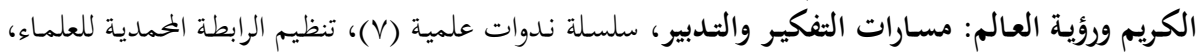




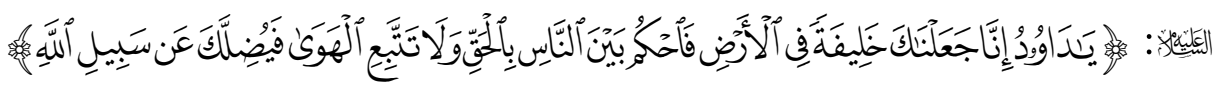

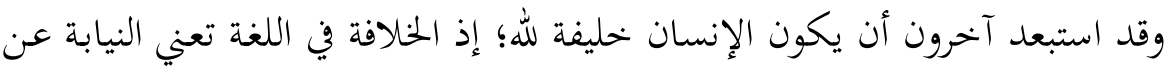

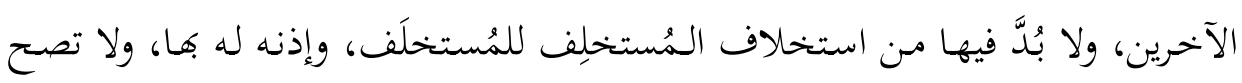

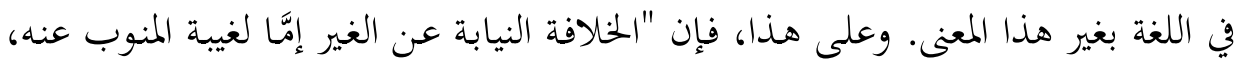

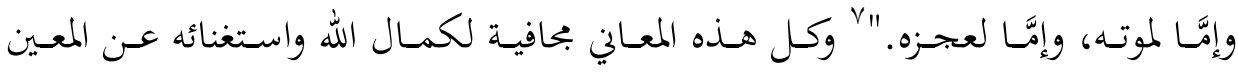

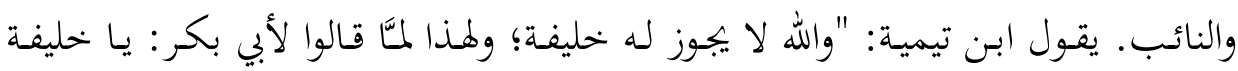

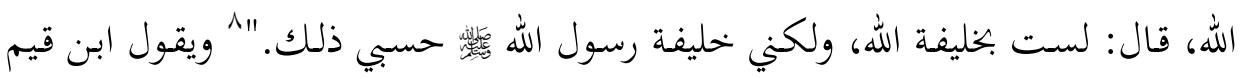
الجوزية: "إن أريد بالإضافة إلى الله أنه خليفة عنه، فالصواب قول الطايفة رسول الطائفة المانعة منها،

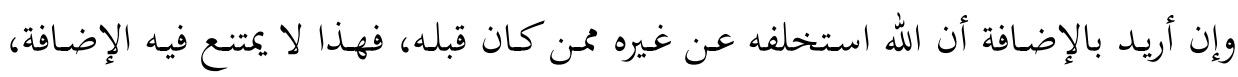

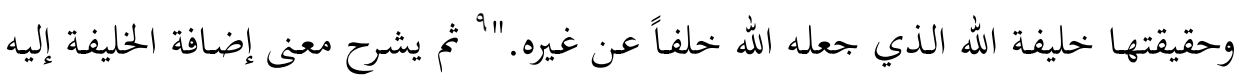

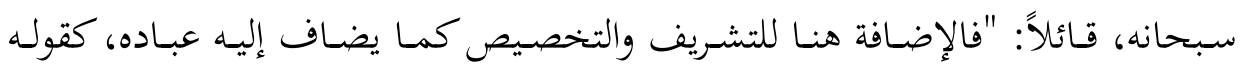

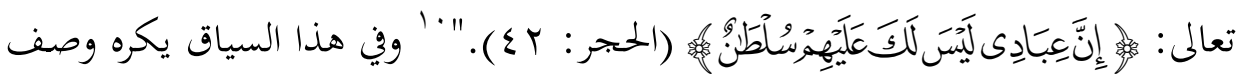

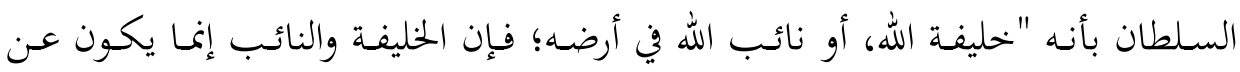

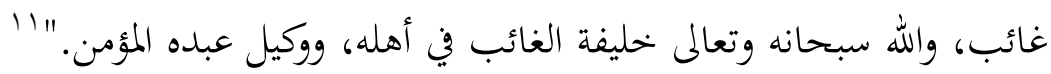
فهذا الاتحاه في التفسير يكصر الخلافة فقط في التعاقب على الأرض، أو تولية الإمارة

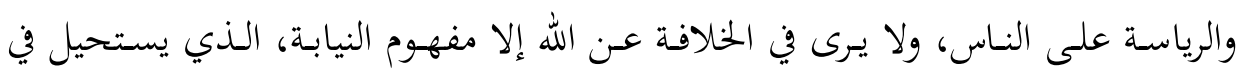

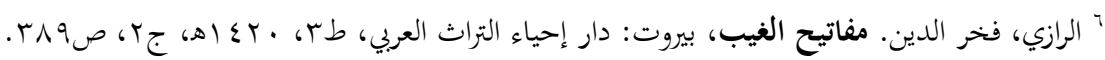

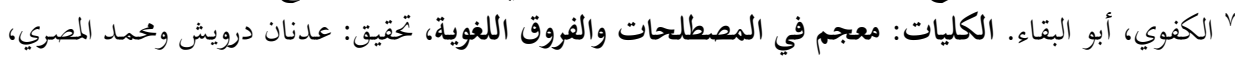

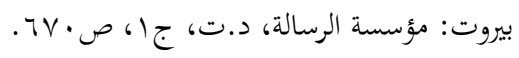

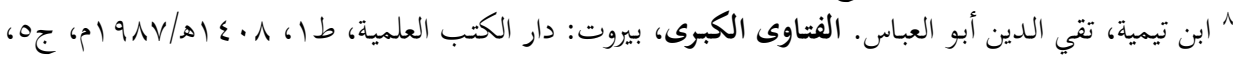

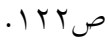
" ابن قيم الجوزية، شمس الدين حممد بن أبي بكر. مفتاح دار السعادة ومنشور ولاية العلم والإرادة، بيروت: دار

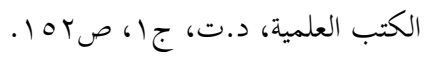

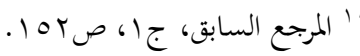

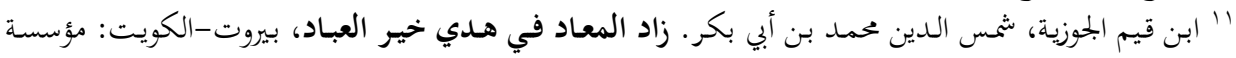

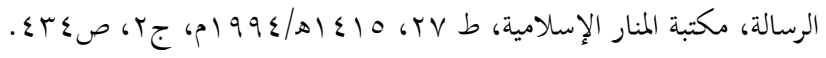


حقه تعالى، مع احتمالها معنى النيابة في حدود ضيقة، يمنح فيها الإنسان حرية الاختيار التي يكون بها مسؤولاً عن إرادته ومعتقده وسلوكه خحلافاً لباقي المخلوقات.

والحرص على استبعاد معاني النيابة عن الله من دلالات الاستخلاف، صرفه غالباً

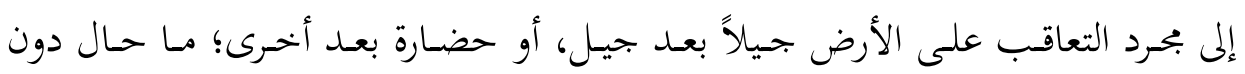

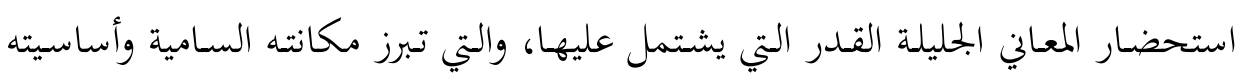

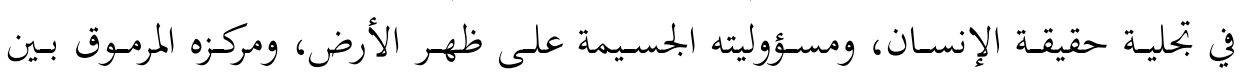

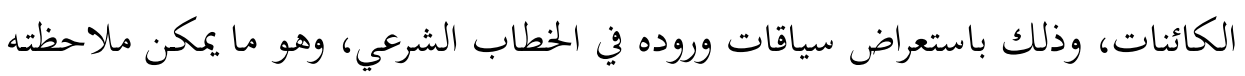

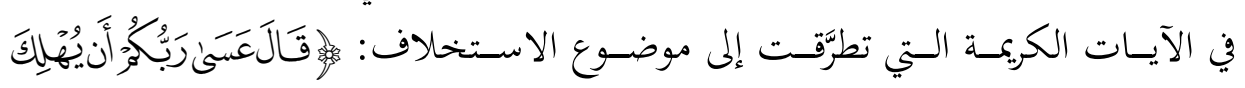

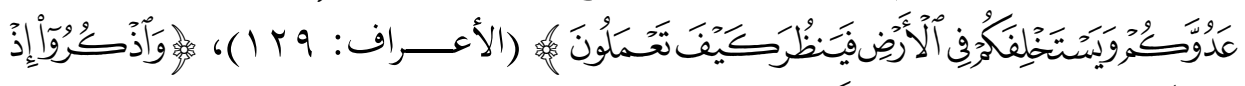

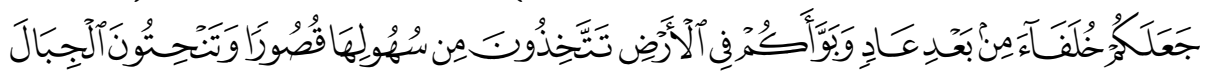

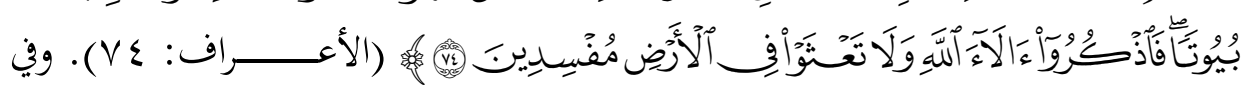

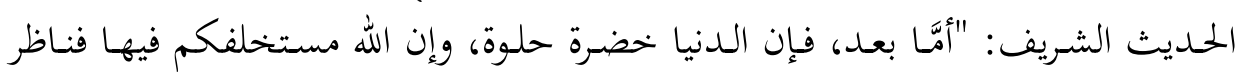

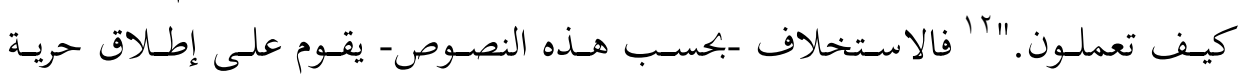

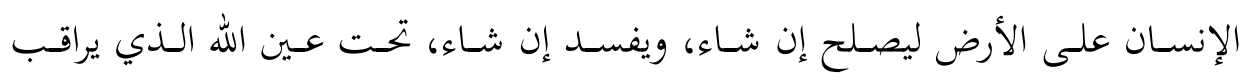

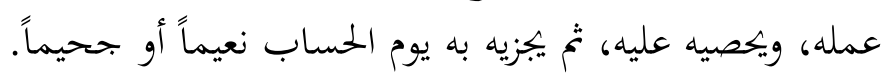

وبهذا الفهم، فإن الاستخلاف هو منح الله تعالى الإنسان مسؤولية الاختيار والفعل في الحياة الدنيا، ثم يتولَّى محاسبته على اختياراته وأفعاله في الدار الآخحرة، وكأن الإنسان الإنسان

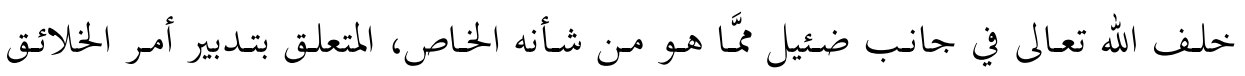

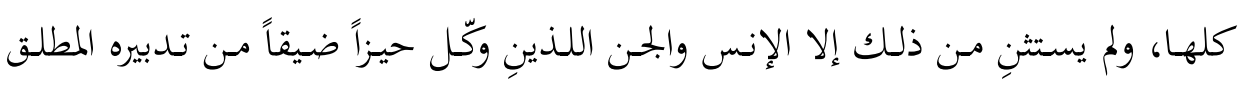

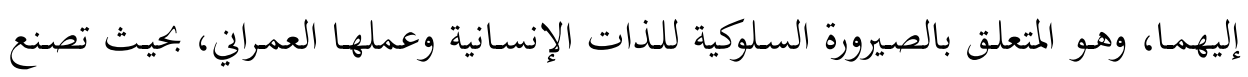
مصيرها بنفسها على الأرض، وفي العالم الآخر.

وهكذا تأخذ خحلافة الإنسان عن الله بُعْداً أخطر وأشرف في ذات الوقت، "بمعنى أن الله تعالى قد أعطاه من قوة العقل والتفكير والتدبير، والسيطرة على نفسه، وعلى مالى ما في

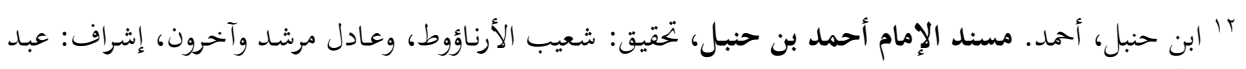

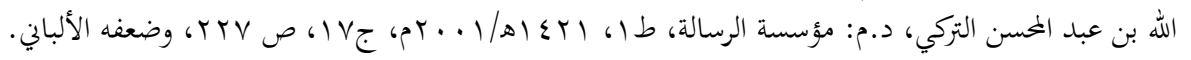




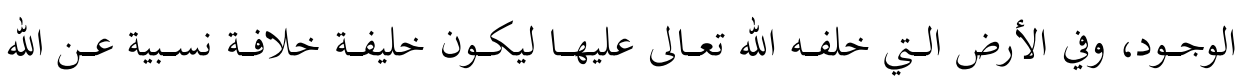
تعالى.

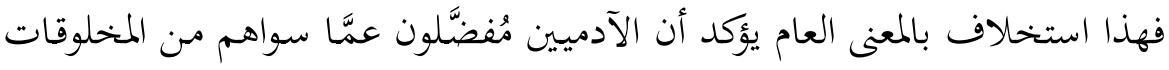

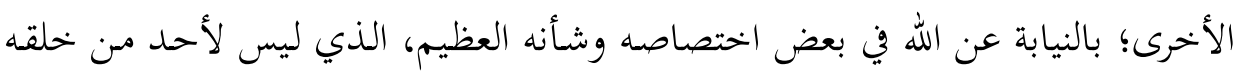

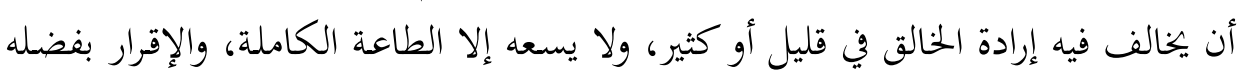

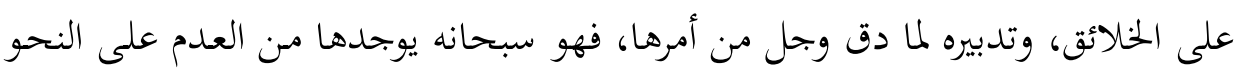

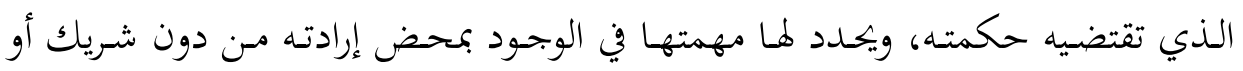
معين، ولا تملك حق الاعتراض عليه أبداً.

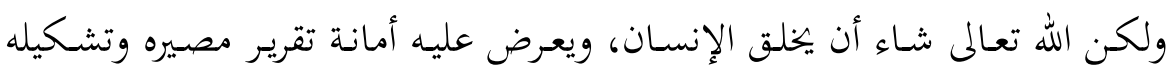

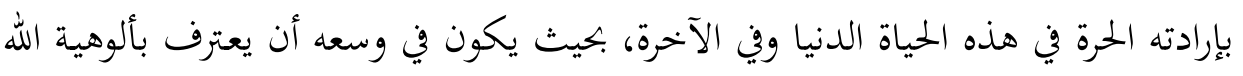

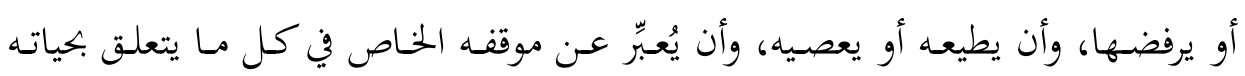

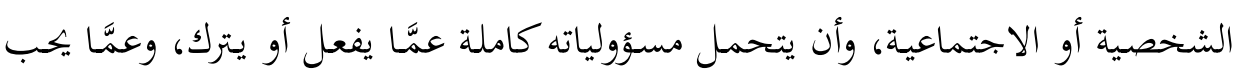

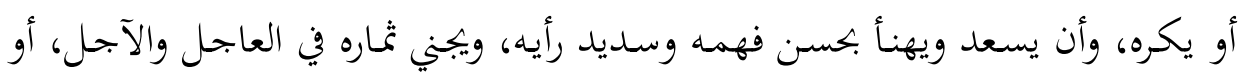

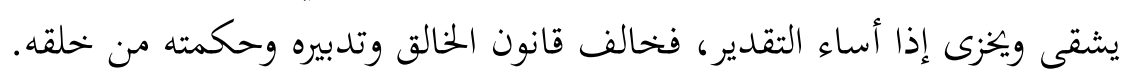

\section{ب. الاستخلاف بمعنى تحمل مسؤولية الحكم والقيادة:}

بعد الحميث عن الاستخلاف العام، ودلالته على حرية الإنسان المقيدة بمسؤوليته

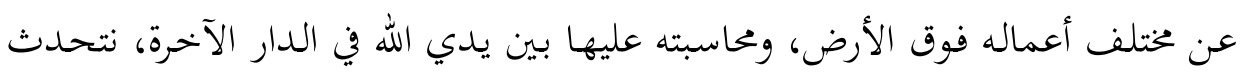

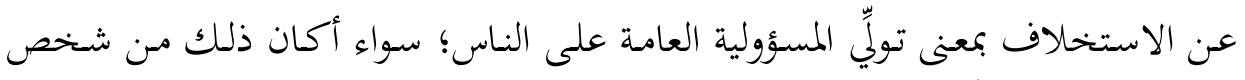

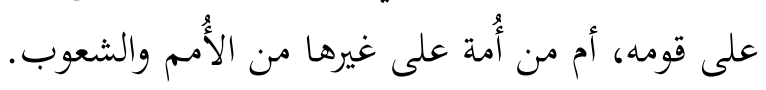

فالفرد الذي يستخلفه قومه عليهم يتحمل مسؤولية عظيمة، تتعلق بتدبير شؤونهم

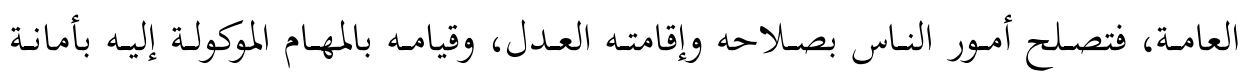

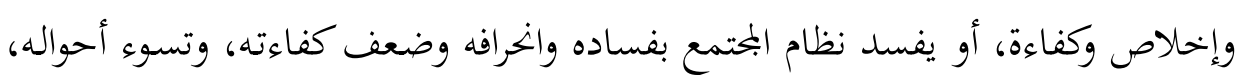
وتفشو فيه المظالم والقلاقل.

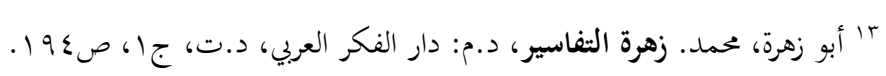




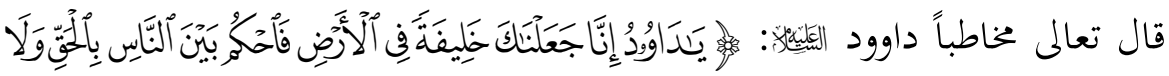

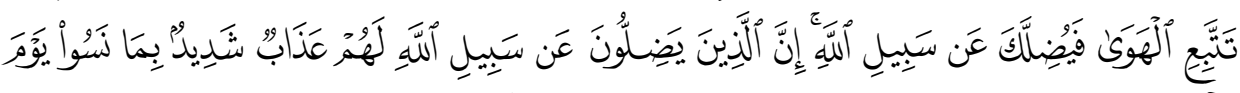

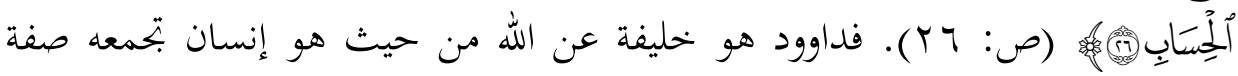

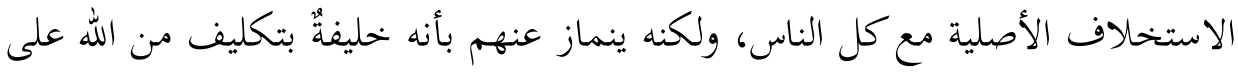

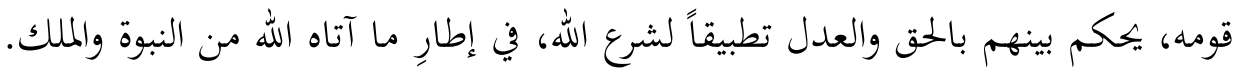

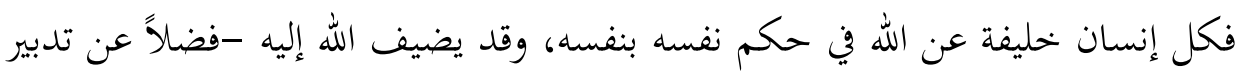

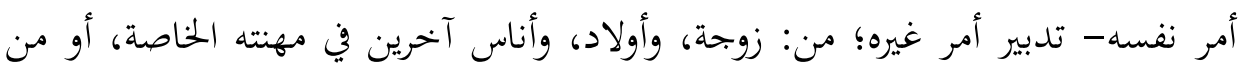
خلال تولّيه مهام إدارية عامة؛ مديراً، أو حاكماً، أو أميراً.

وقد يستخلف الله قوماً على غيرهم؛ استحقاقاً لهم على قدر التزامهم بالاستقامة

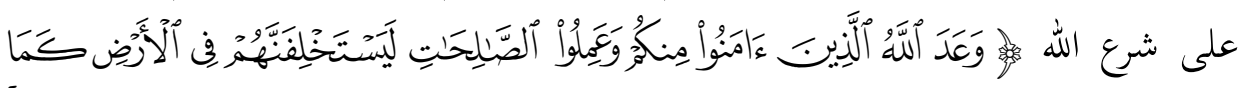

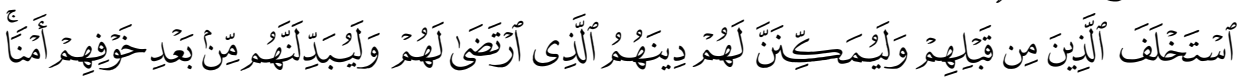

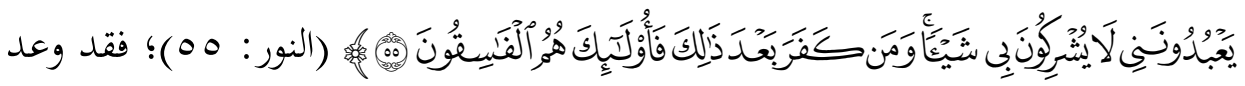

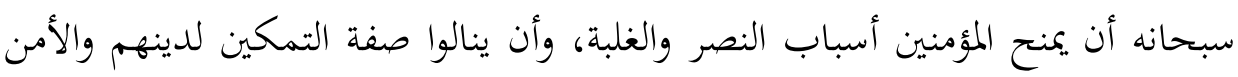

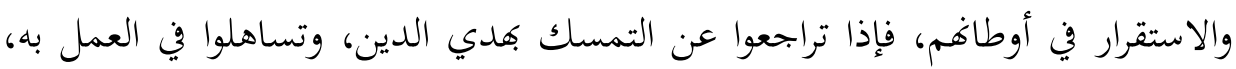
دبَّ إليهم الوهن والفساد، وخسروا العزة في دنياهم والفوز في أُخراهم.

والاستخحلاف تكليـف واختبـار للفئسة المؤمنـة، التي إذا تيـأت لهـا ظروف الريـادة

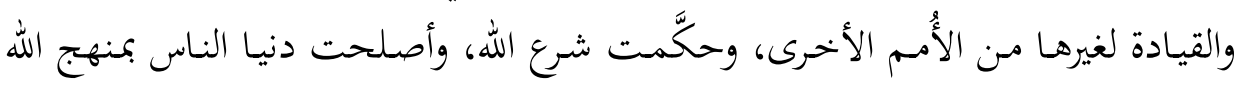

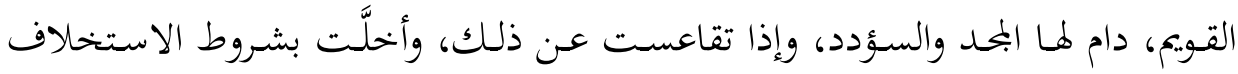

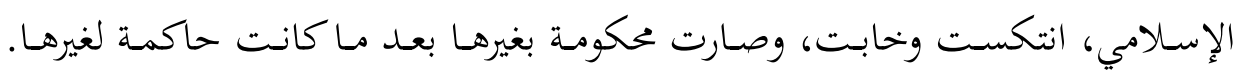

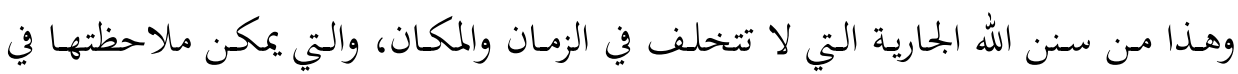

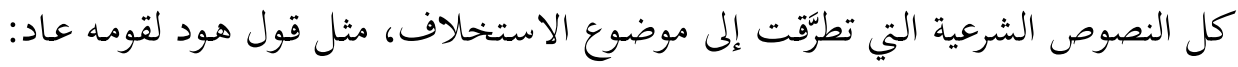

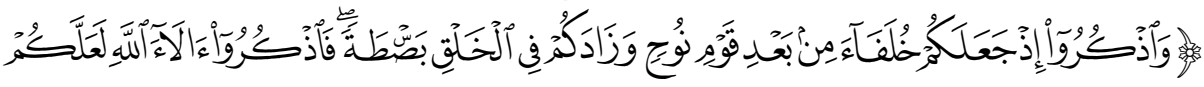

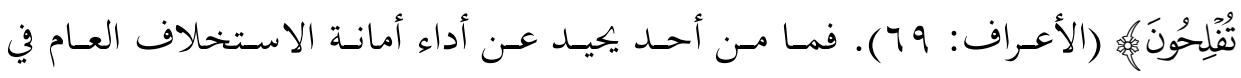
الأرض إلا استبدل الله به غيره، ممن تؤول إليه الهيمنة على شؤونه العامة والخاصة. 
ت. الاسـتخلاوف بمعنسى النيابـة بـين النساس فـي تــأمين مصــالحهم الفرديسة

والجماعية:

إن الخلافة بمعنى النيابـة في إطار حرية الإنسان ومسؤوليته، تتسع أيضاً لخلافة بني

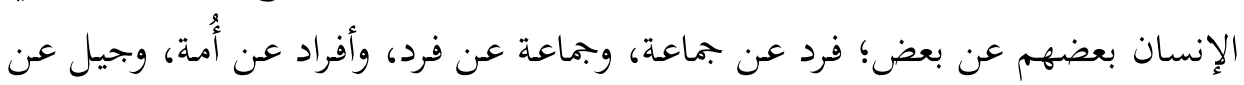
جيل، وخلف عن سلف. فالحاكم يخلف الشعب في تدبير شؤونه العامة. وكل فرد يمارس الخلافة من خحلال مهنته أو وظيفته المعلومة في المجتمع؛ لتأمين خدمة معينة لمصلحة غيره

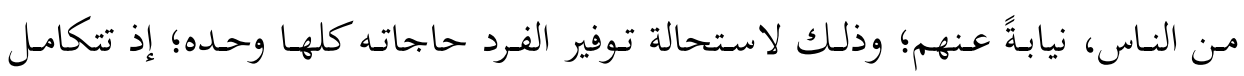

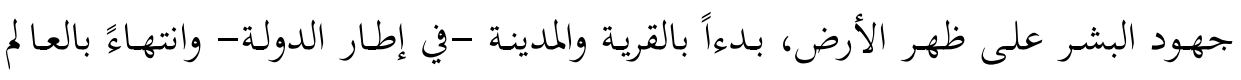

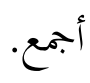

وأمَّا العلماء ورجال الفكر والتربية والتوجيه فيخلفون الأُمة في رعاية تدينها، وحمايته

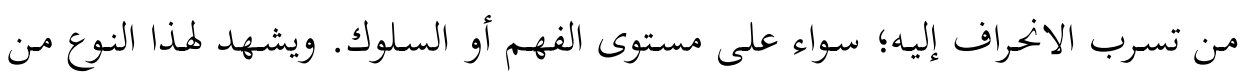

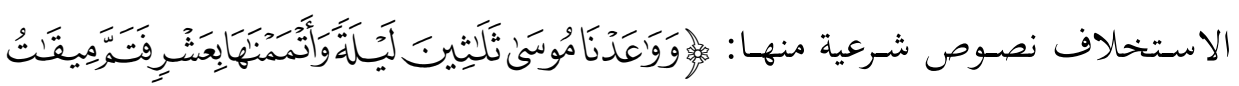

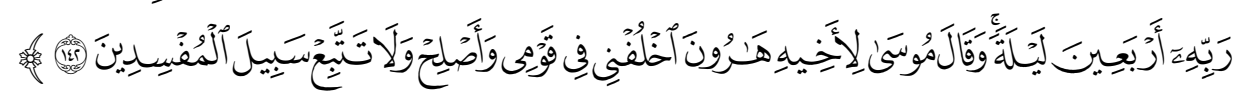

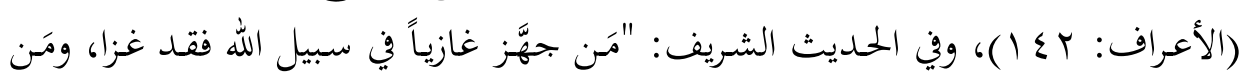

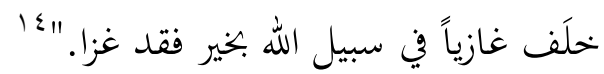

والاستخلاف بهـا المعنى - كغيره مـن أنواع الاستخلاف الأخهرى- يتوقف على كيفية ممارسة كل فرد للأمانة، التي هي أساس الاستخلاف في الأرض، ومدى تمثل قيمها

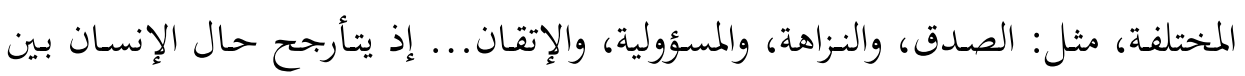

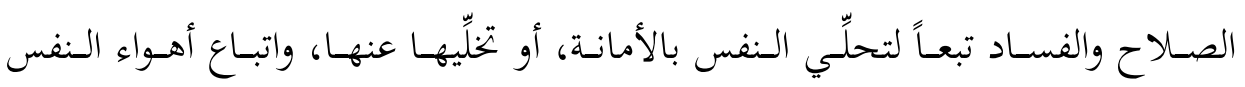
وشهواتها.

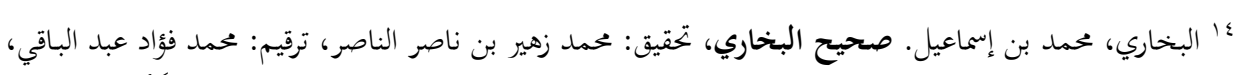

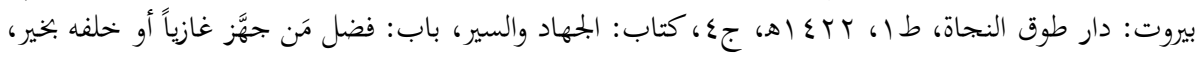




\section{r. r. مسوغات اعتبار الاستخلاف مقصداً عاماً للمقاصد الإسلامية:}

\section{أ. أسبقية مقصد الاستخلاف على غيره من المقاصد:}

بيَّن الله تعالى مقصده مـن خلق الإنسان حين أخسبر الملائكة أنه سيستخلفه في

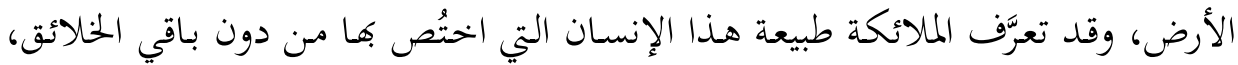

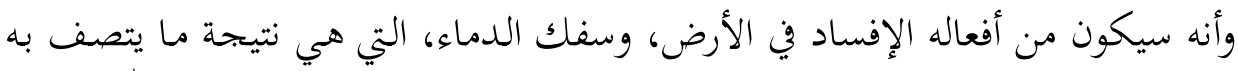

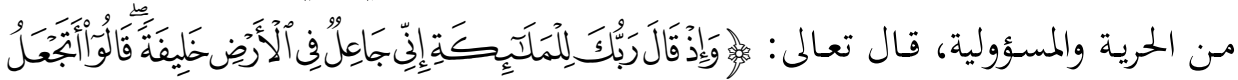

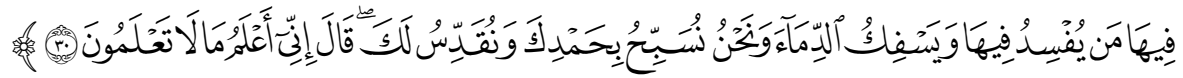

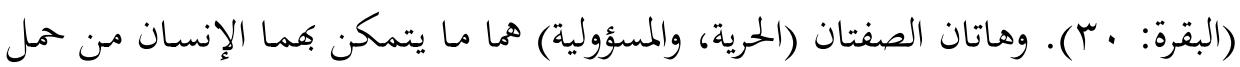

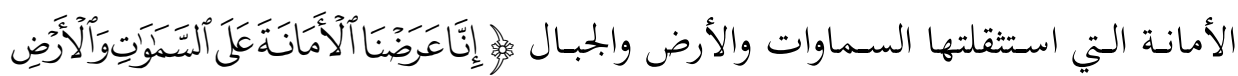

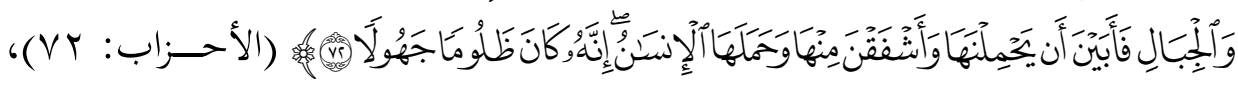

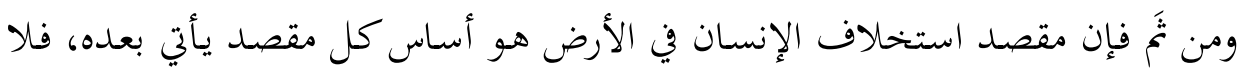

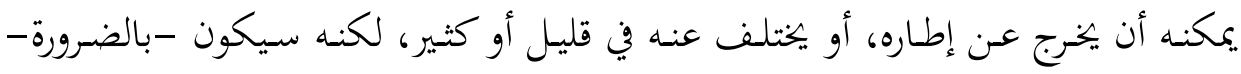

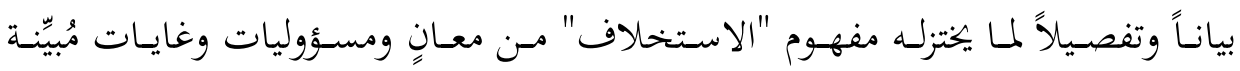

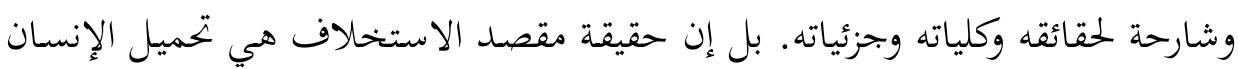

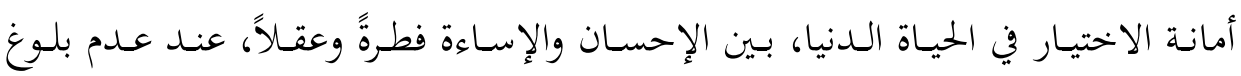

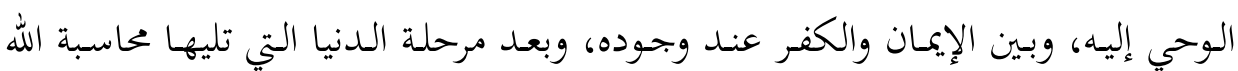
على الاختيارات، وتحمل تبعاتما في الآخرة.

\section{ب. ارتباط الاستخلاف بمسؤولية الإنسان:}

لقد أحيط حدث استخلاف الإنسان بما ينبئ عن عظم شأنه، وخطر أمره، وأنه

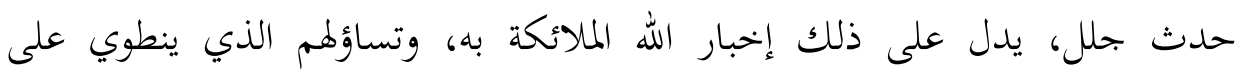

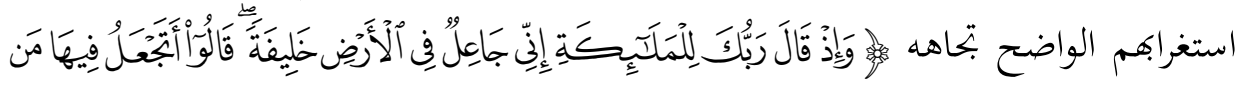

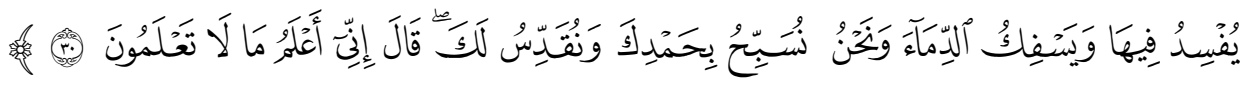


فقد علمت الملائكة من خصائص هذا الكائن المُستخحلَف أنه -خحلافاً لما هـم عليه

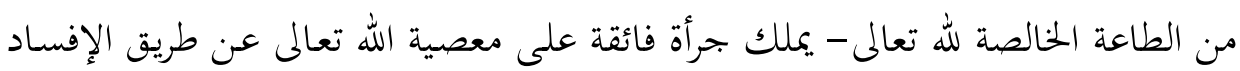

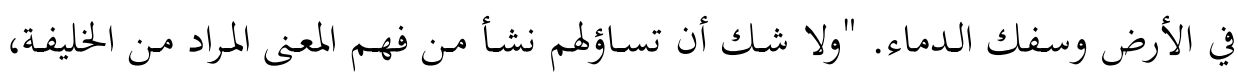

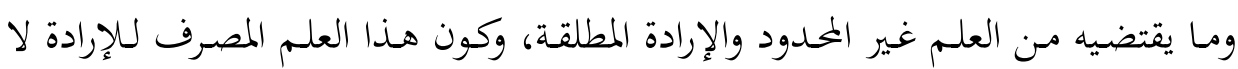
يحصل إلا بالتدريج، وكون عدم الإحاطة مدعاة للفساد والتنازع المفضي إلى سفك الدماء

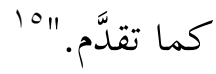

وقد توالت الآيات القرآنية التي تصف الملائكة بالانقياد التـام لأمر الله الذي لا يشوبه زيغ أو فتور، كما هو شأن باقي المخلوقات في الكون، غير الجحن والإنس، منها

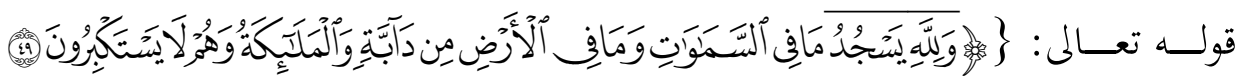

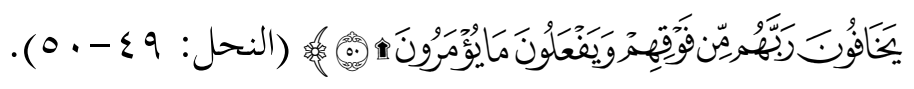

فعنـدما "أخهبر الله الملائكـة بأنهـ جاعـل في الأرض خليفـة، فهمـوا مـن ذلك أن الله يودع في فطرة هذا النوع الذي يجعله خليفة، أن يكون ذا إرادة مطلقة واختيار في عمله إنه

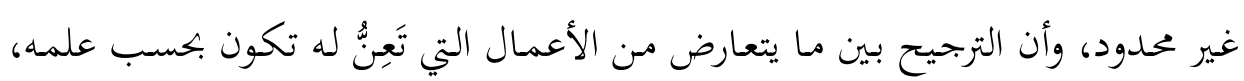

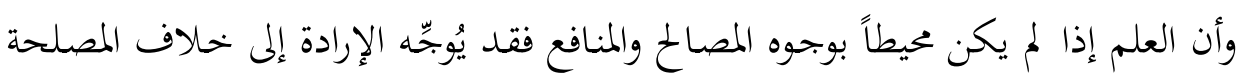
والحكمة، وذلك هو الفساد... فعجبواكيف يخلق الله هذا النوع من الخلق، وسألوا الله

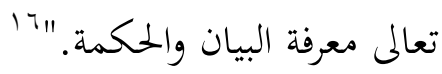

فالاستخلاف عن الله يرتبط أساساً بتمكين الله الإنسان من حرية التصرف في نفسه

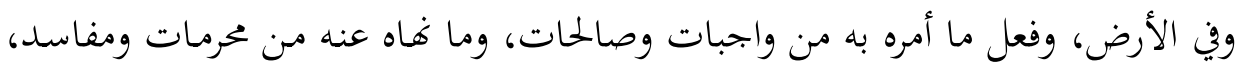

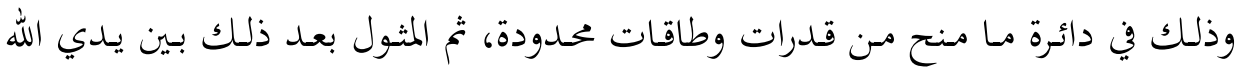

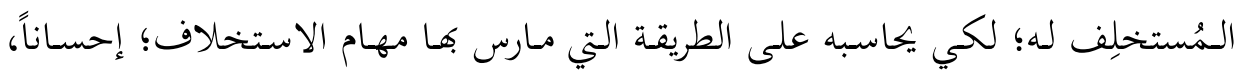
وإصلاحاً، أو إساءةً، وإفساداً.

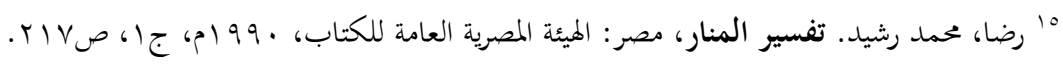

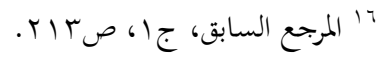


ثانياً: بيان كون الاستخلاف مقصداً عاماً للقرآن والشريعة والحضارة

\section{1 ـ الاستخلاف بوصفه مقصداً عاماً للقرآن الكريم:}

يمكن القول إن أساس استخلاف الإنسان في الأرض هو مـا زوَّده الله به مـ فطرة

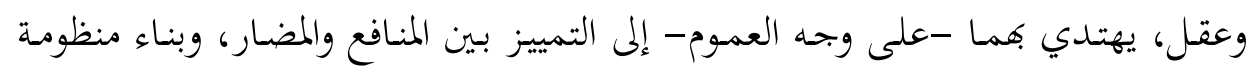

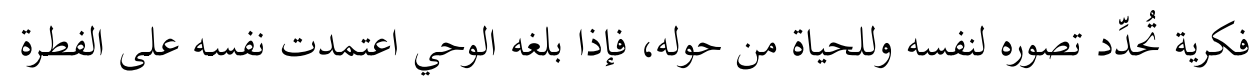

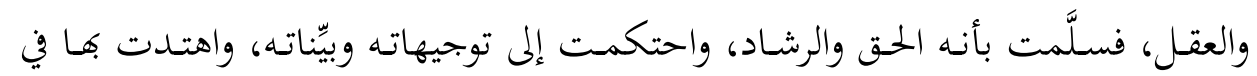

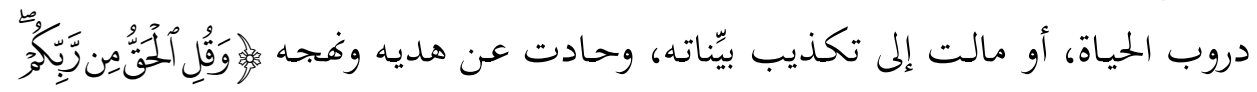

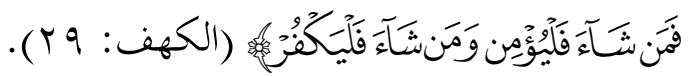

يقول عباس محمود العقاد: "الإنسان في عقيدة القرآن هو الخليفة المسؤول بين جميع

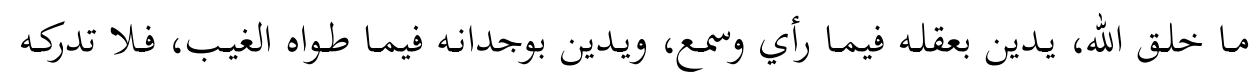

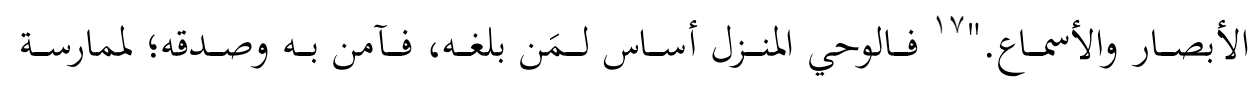

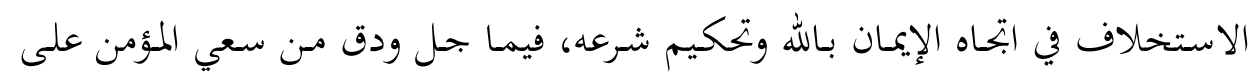

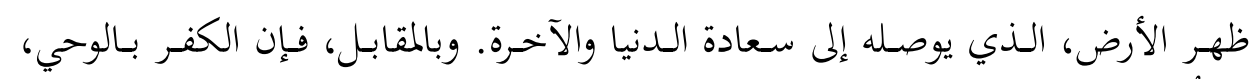

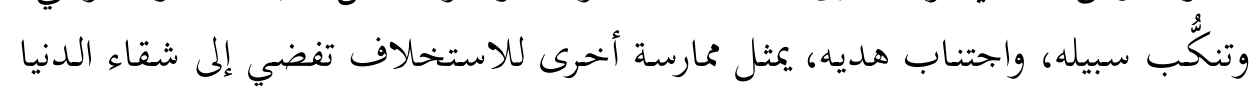
والآخرة.

فالاستخلاف الإنساني لا يخرج عن أحد مسارين: مسار يتوجه فيه الآدمي في حياته

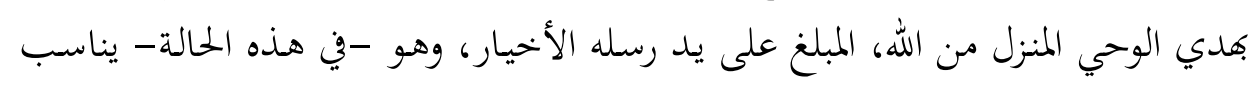

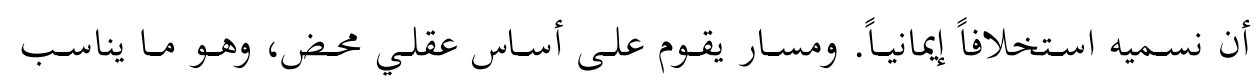
تسميته بالاستخلاف الوضعي.

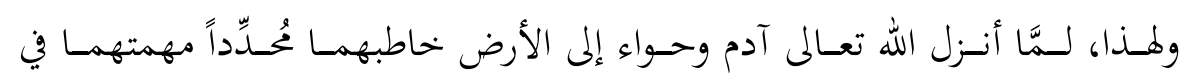

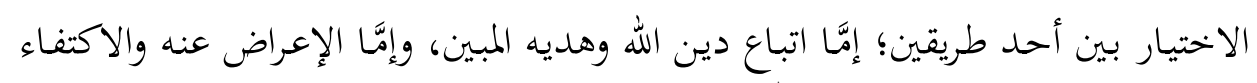

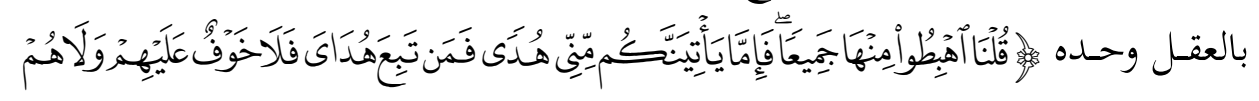

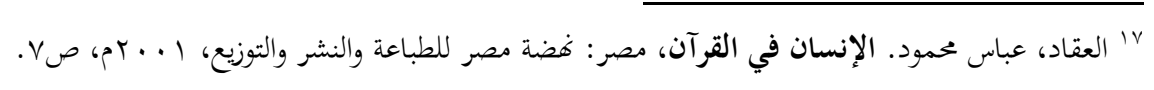




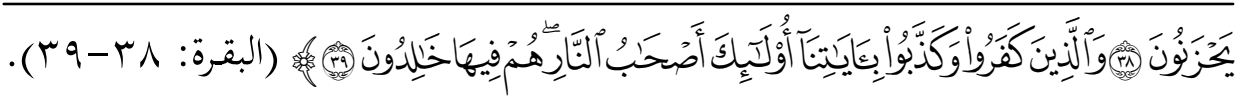

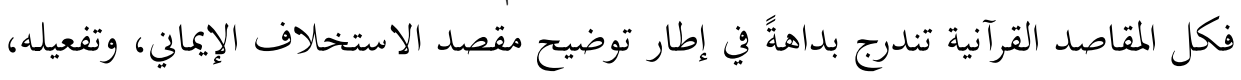

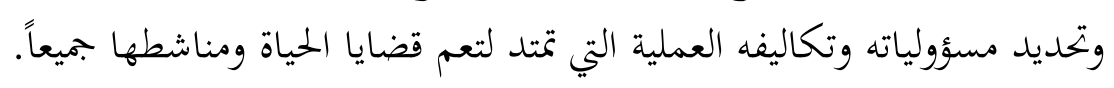

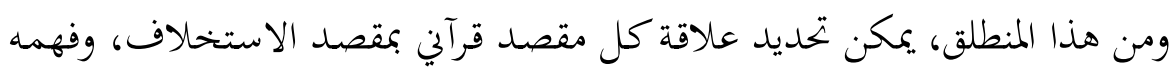

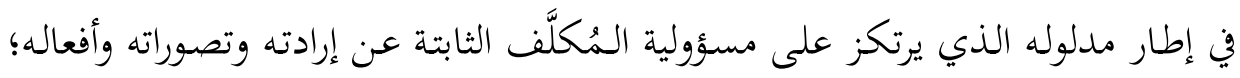

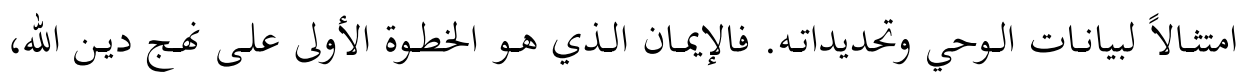

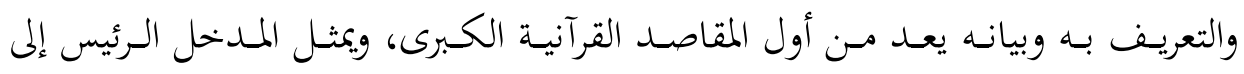

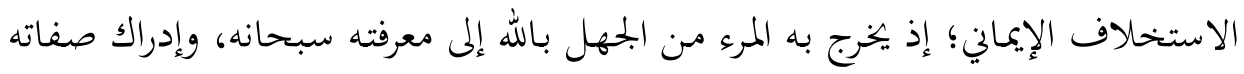

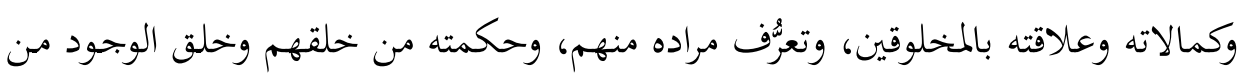

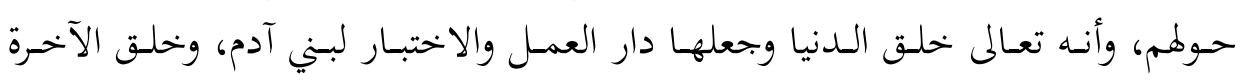
وجعلها دار الجزاء بالنعيم الأبدي، والعقاب بلنار البناب الجحيم.

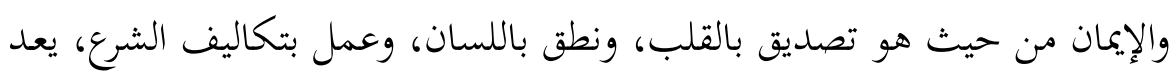

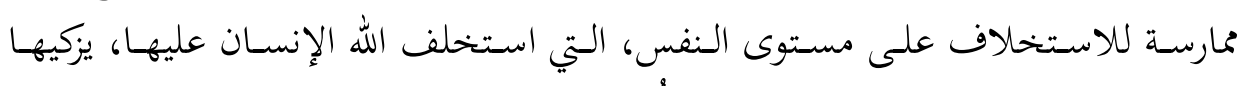

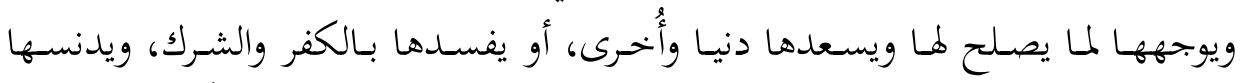

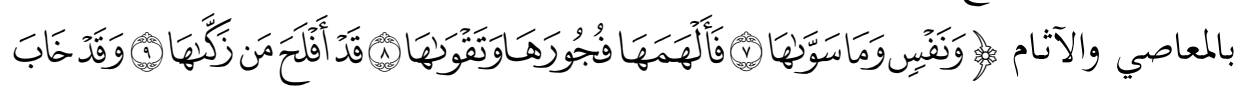

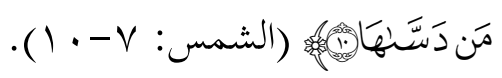

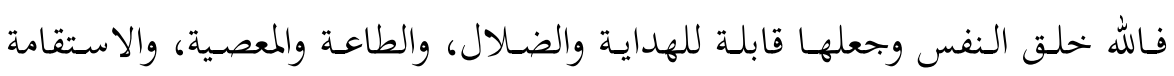

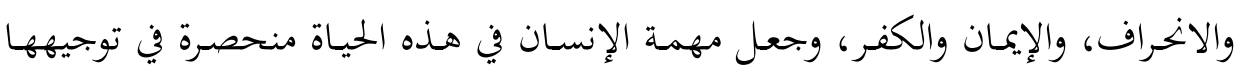

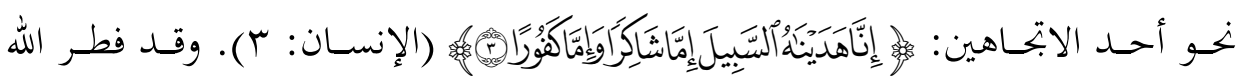

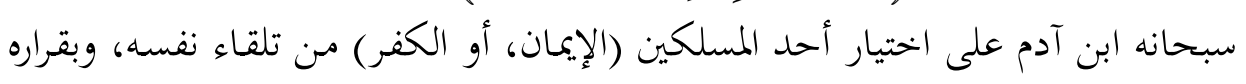

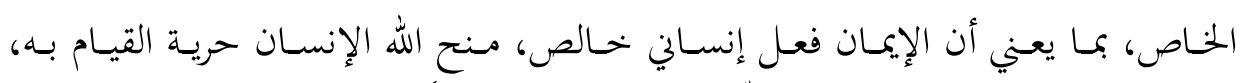

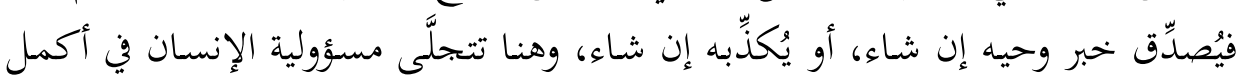

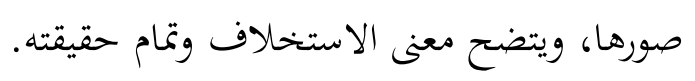

فإذا حسم اختيار الإيمان في قرارة نفسه، وأكد عزمه عليه، وباشر مقتضياته العملية، ولئه

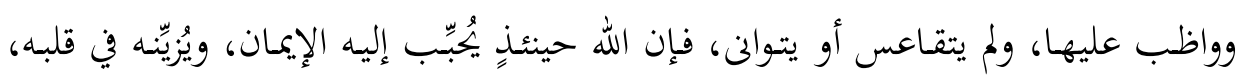




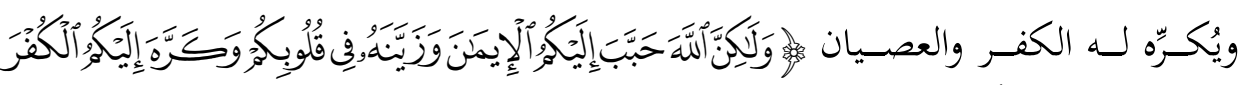

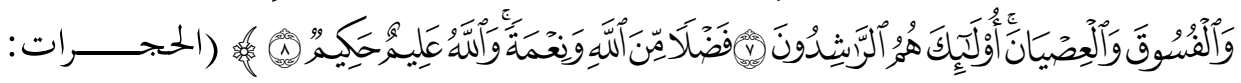

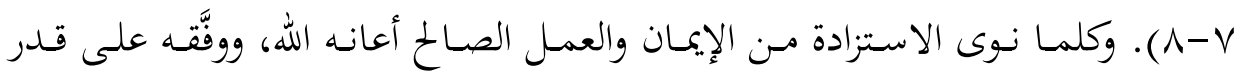

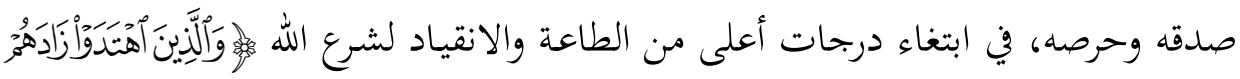

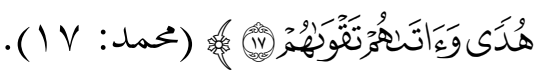

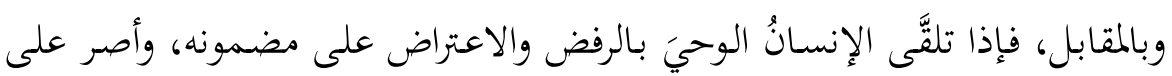

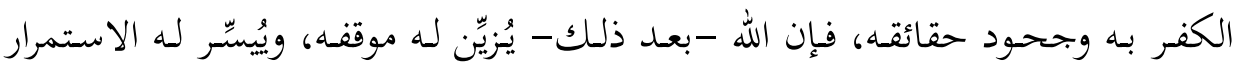

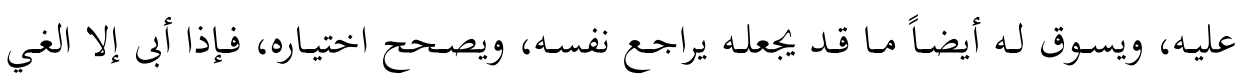

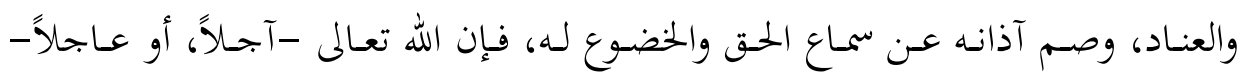

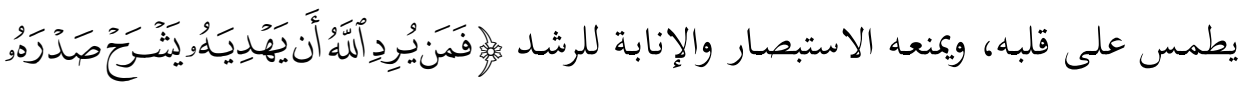

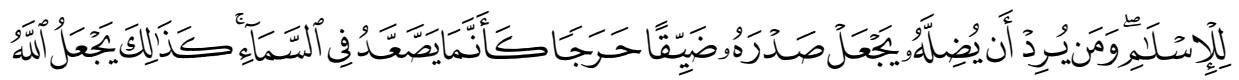

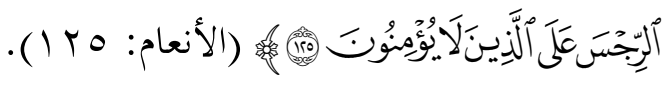
وهكذا نخلص إلى أن الإيمان هو ممارسة استخلافية تأسيسية لكثير من التصورات

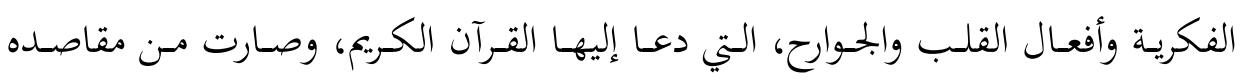

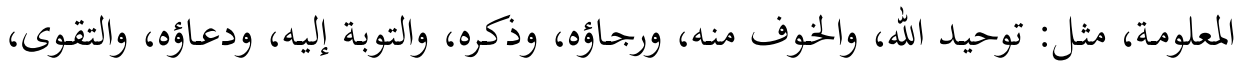

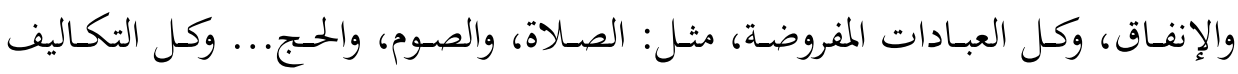

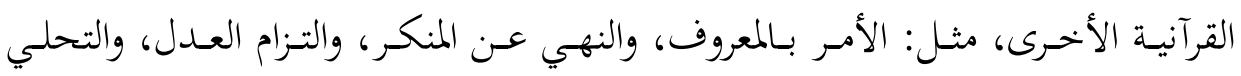

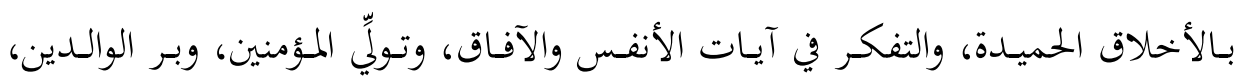

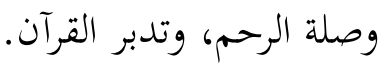

وكل هذه المقاصد وأمثالها تعد امتداداً لمقصد الاستخلاف، وتطبيقاً سلوكياً له؛ فمن

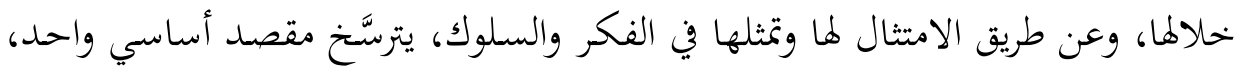

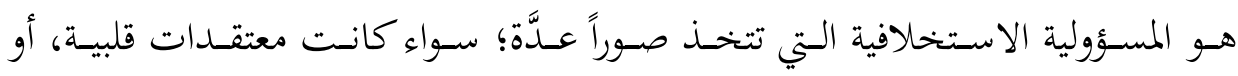
التزامات سلوكية، أو مزيجاً بينهما. 


\section{Y. الاستخلاف بوصفه مقصداً عاماً للشريعة الإسلامية:}

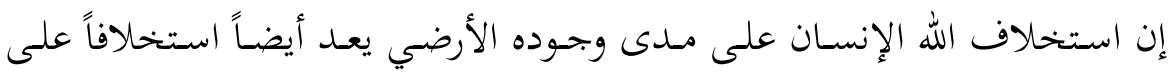

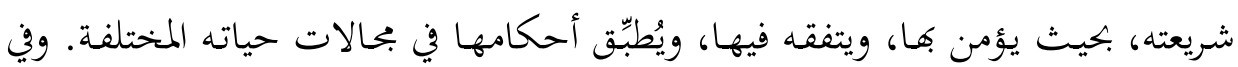

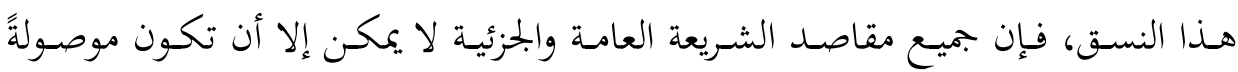

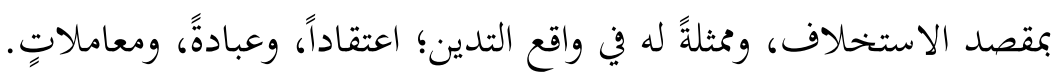

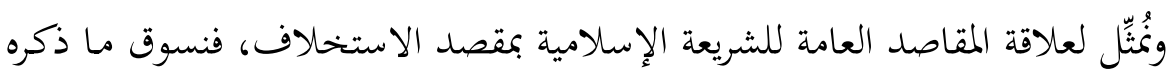

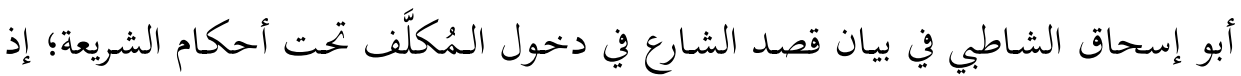

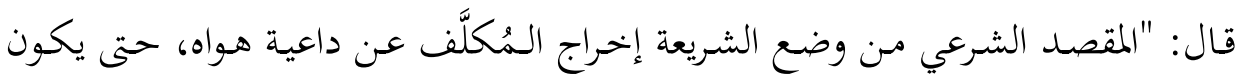

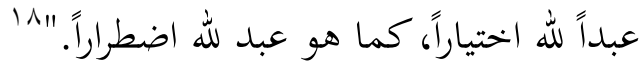

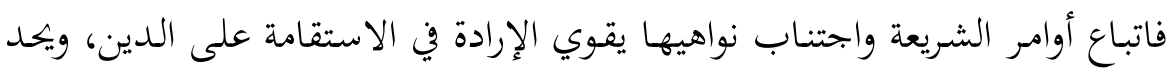

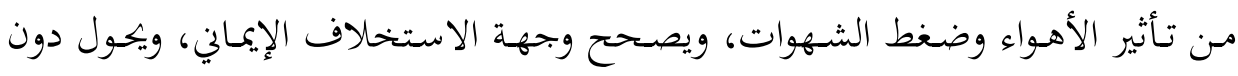

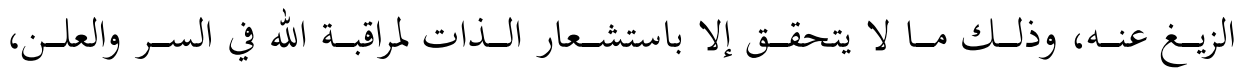

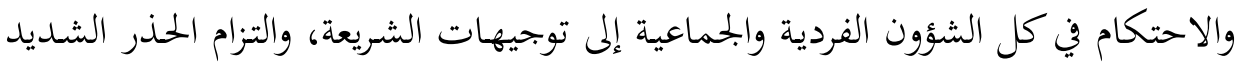
من اتباع الهوى الذي يبتعد بالنفس عن هدى الله والحق المبين.

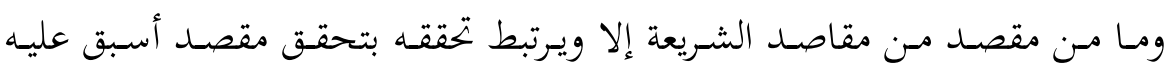

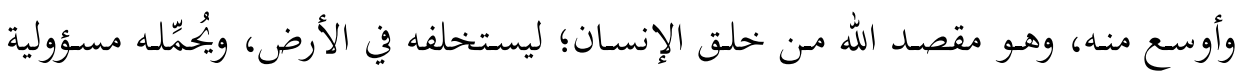

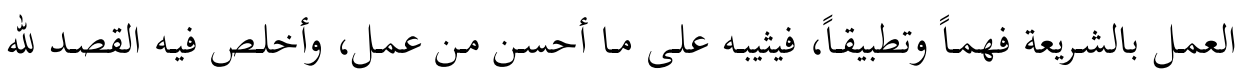

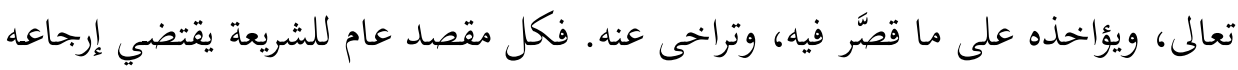

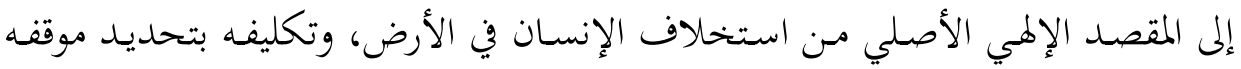
النظري والسلوكي من الوحي والشريعة المنزلة.

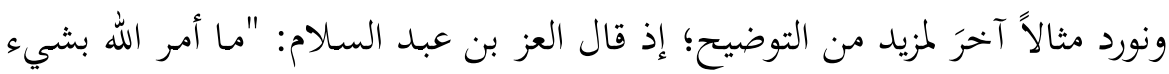

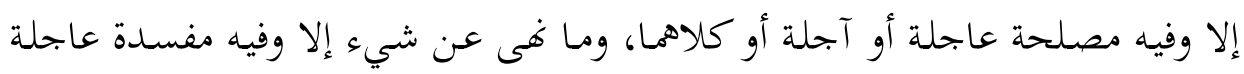

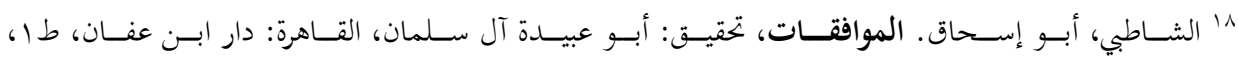
.rq. - r人q9، 


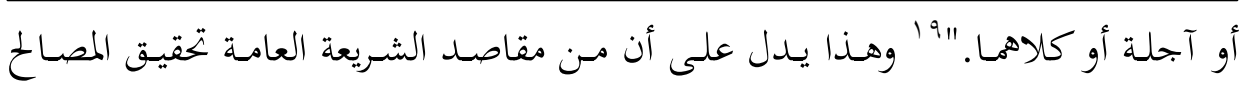
وتكثيرها، ودفع المفاسد وتقليلها.

ولكـن يلزم وضع هـذا المقصد في إطـار المقصد الإلهي الأسمى مـن خلق الإنسـان

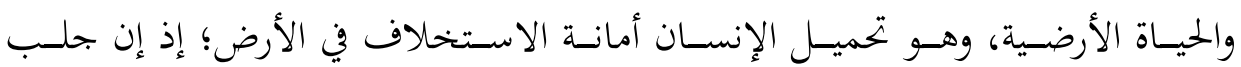

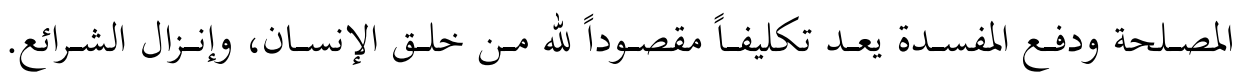

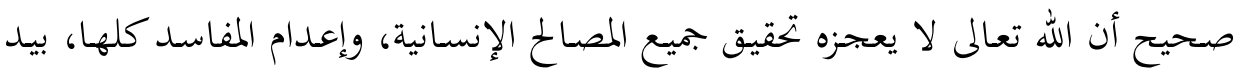

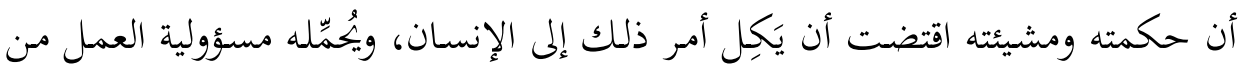

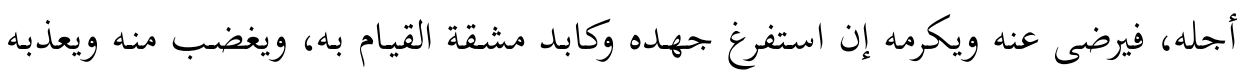

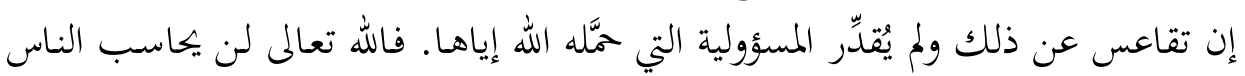

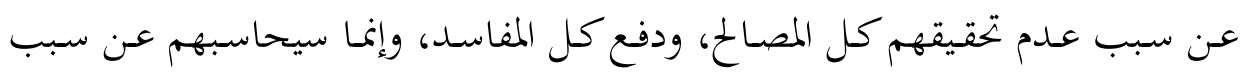

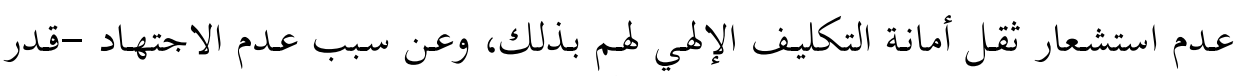

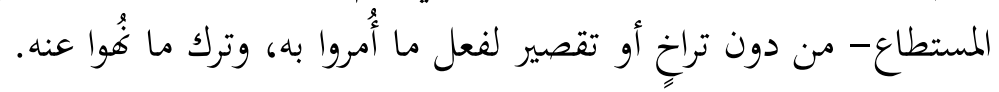

وسـعياً لتـأطير مقاصـد الشـريعة بالمقصـد الأسـاس الـذي هـو الاسـتخلاف، يمكنتـا استحضار بُعْد التكليف والابتلاء عند صياغة أي مقصد، على نهو المثالين الآتيين: - المقصـد العـام للشـريعة الإسـلامية هـو تكليـف الإنسـان بجلـب المصـالح، ودفع

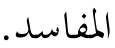
- المقصد الشرعي من وضع الشريعة هو تكليف الإنسان بإخراج نفسه عن داعية هواه؛ ليكون عبداً لله اختياراً، كما هو عبد الله اضطراراً.

\section{ب. الاستخلاف بوصفه مقصداً عاماً للعمران الإنساني والإسلامي:}

\section{أ. الاستخلاف مقصد عام للعمران الإنساني:}

لقـــــط رالله مهمـة استخحلاف الإنسـان بمجـال الأرض التي سيعيش على ظهرهـا،

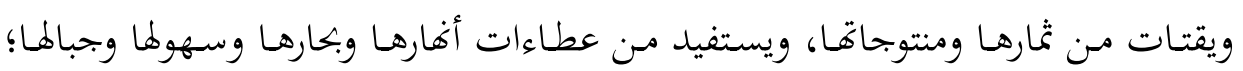
919 ابن عبد السلام، عز الدين أبو محمد. الفوائد في اختصار المقاصد، تحقيق: إياد خالد الطباع، دمشق: دار 


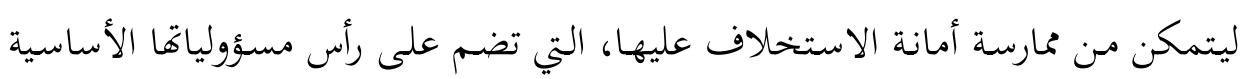

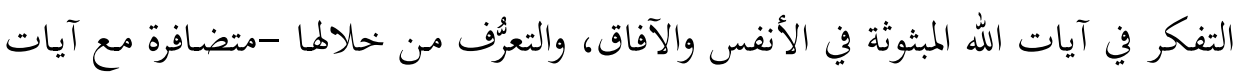

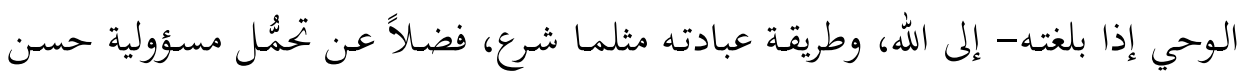

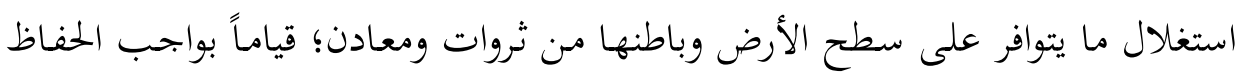

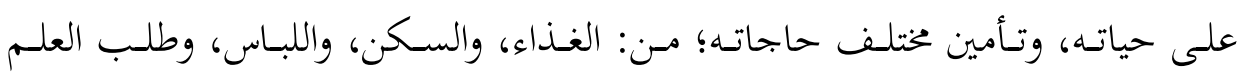
النافع، والتماس العلاج الطبي، وضمان ترقية وجودهه بتطوير العلوم الزراعية والصناعية.

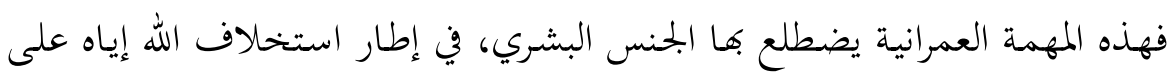

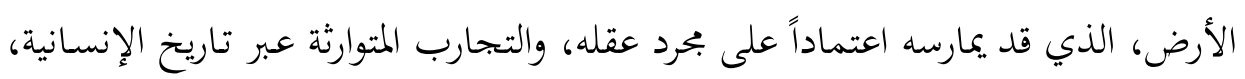

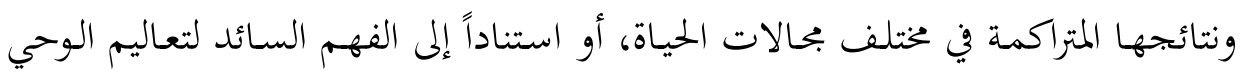

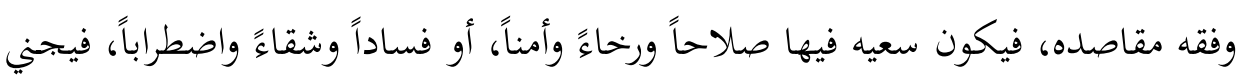
تثمار فهه العاجلة فوق الأرض، ويتعرض لحساب الله الآجل في الدار الآخرة.

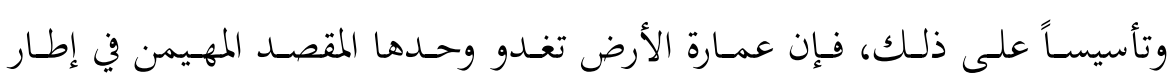

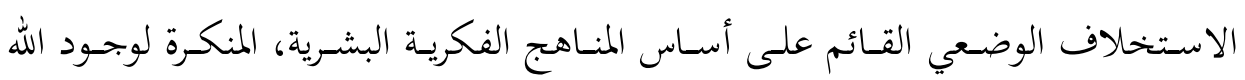

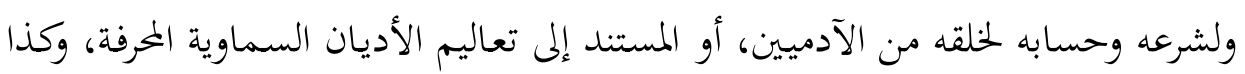

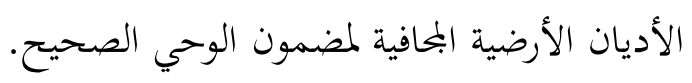

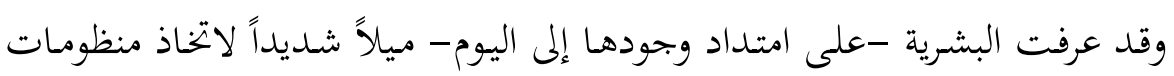

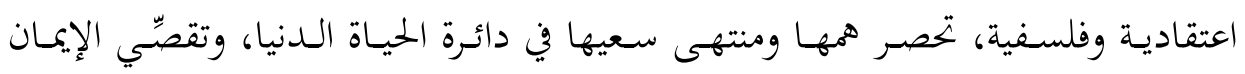

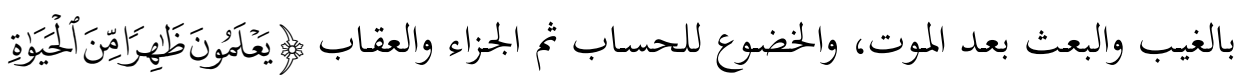

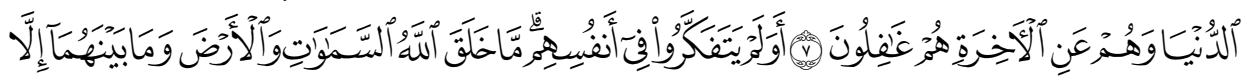

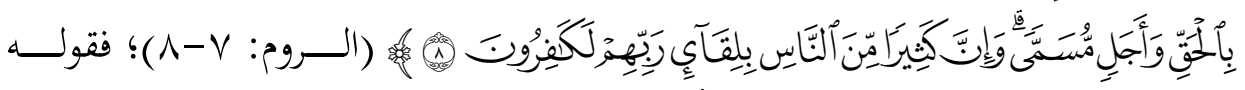
تعالى: $\}$

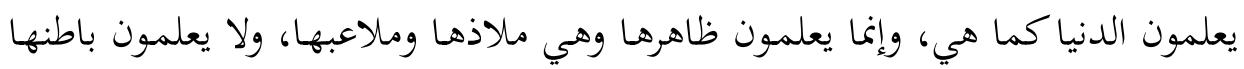

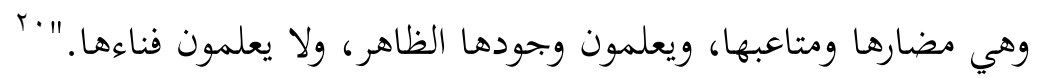

•r الرازي، مفاتيح الغيب، مربع سابق، جهr، صام. 
وهؤلاء هـم أصحاب الدنيا الذين آثروا القيـام بمهام الاستخلاف؛ بحبس همهـم،

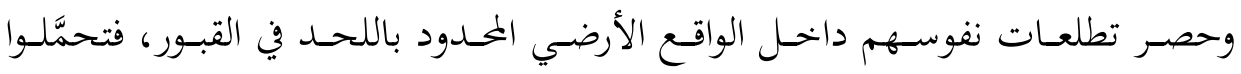
مسؤولية فهمهم الخطأ، فخابوا في الدنيا، وخسروا في الآخرة. وخلاصة القول إن الفعل البشري العمراني -في أي ابتحاه جرى زماناً ومكاناً- يمثل

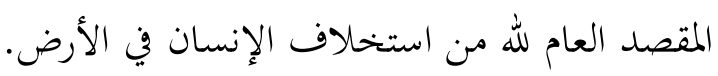

\section{ب. الاستخلاف مقصد عام للعمران الإسلامي:}

إذا كانت الإنسـانية تمارس مهام العمران في الأرض، في ظل منـاهج فكرية وضعية،

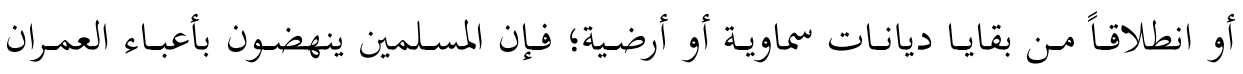

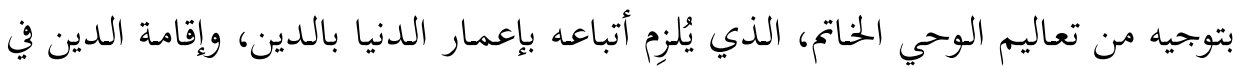

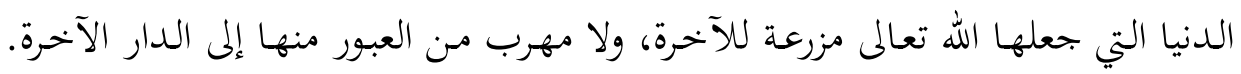

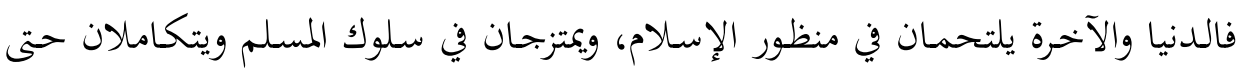

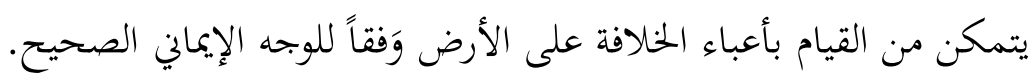
وقــ رسـم القـرآن الكـيم المـنهج الإسـلامي لابتغـاء الحيـاة الآخـرة الباقيـة بالعمل في

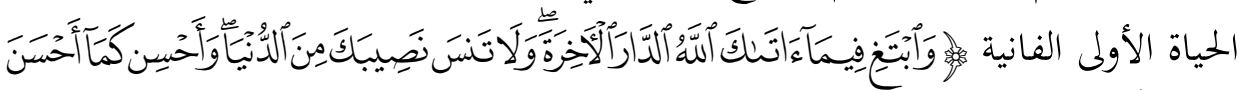

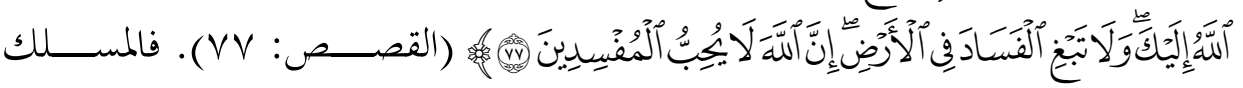

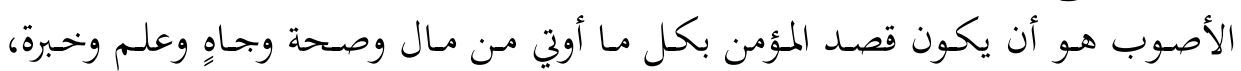

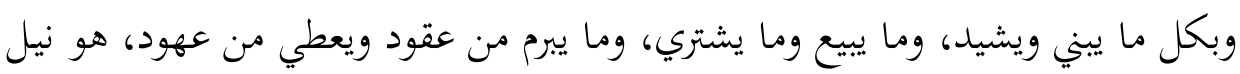

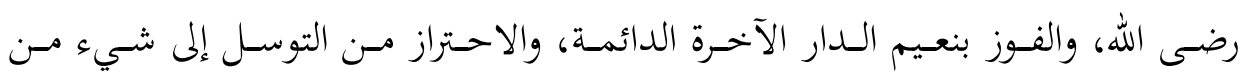
مكاسب الدنيا بما يفسدها ولا يجل في شرع الله. لله. فالدنيا دار ابتلاء وامتحان، والآخرة دار ثواب وجزاء، وهي وكل ما يشغل المُكلَّف

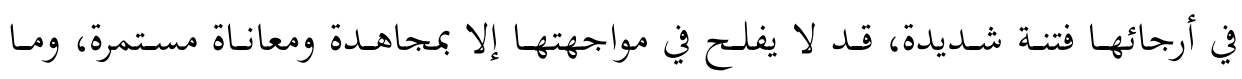

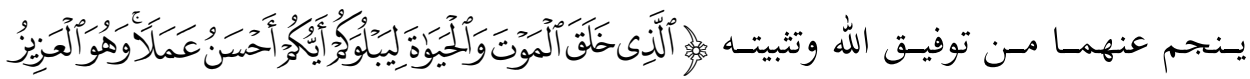

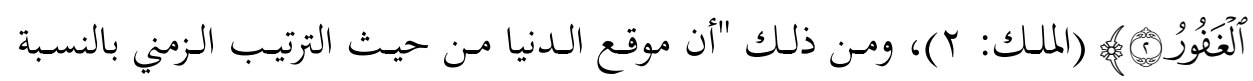


للآخرة يعد من أقوى عوامل الابتلاء. فالنفس البشرية تُؤثر العاجل على الآجل، وتتسرع

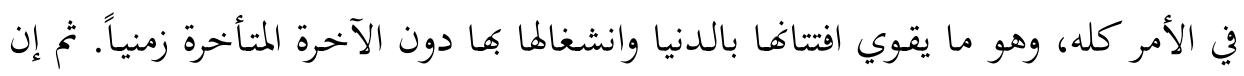

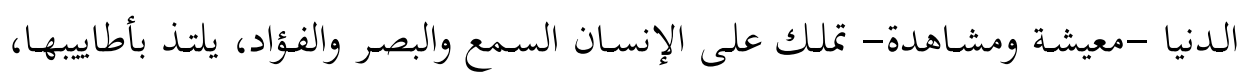

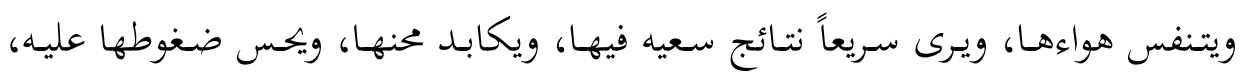

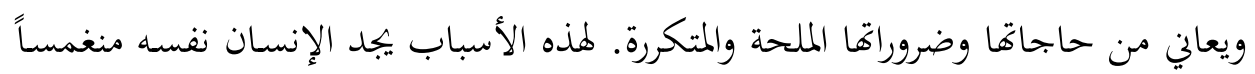

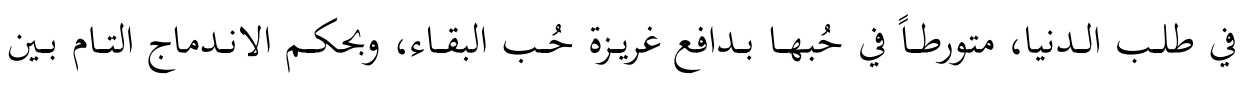

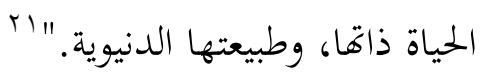

والمسلم يؤمن بأن خلافته النسبية عن الله - كما سلف - لا تجعل مهامه العمرانية

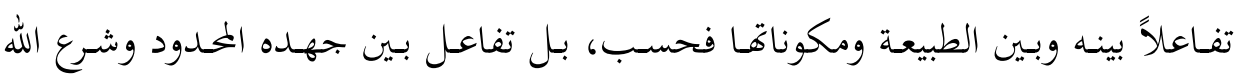

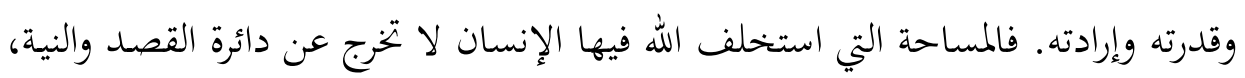

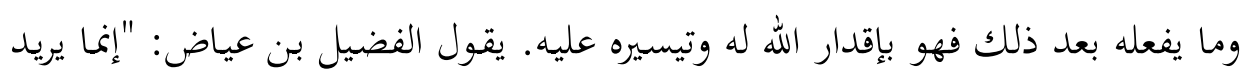

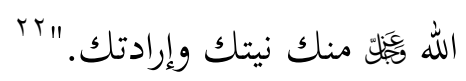

وقد ذهب علال الفاسي إلى اعتبار عمارة الأرض مقصداً عاماً للشريعة الإسلامية، فقال: "والمقصد العام للشريعة الإسلامية هو عمارة الأرض، وحفظ نظام إلى عمار التعايش فيها،

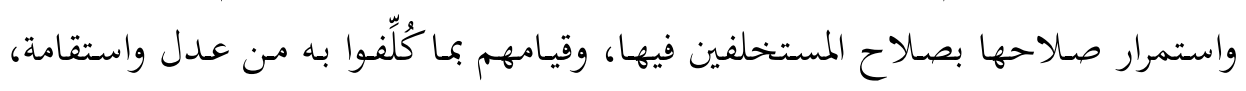

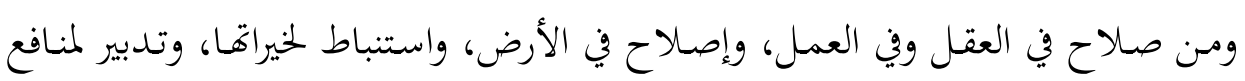

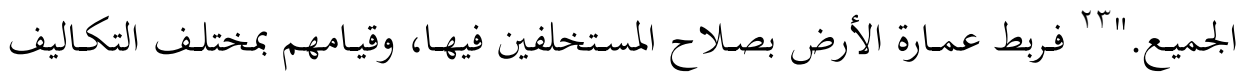

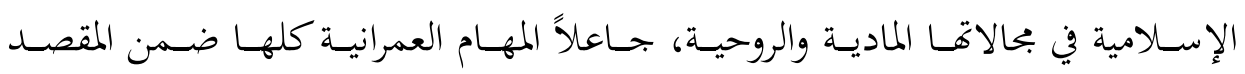
الاستخلافي الذي تَحََّد قبل خلق آدم وحواء، وترسَّخ بالممارسة الفعلية خحلال الإبحازات العمرانية المتميزة للحضارة الإسلامية.

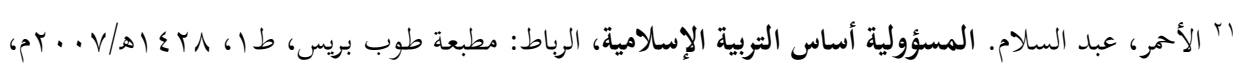

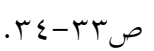

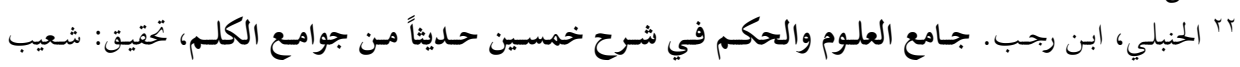

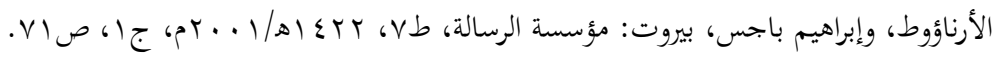

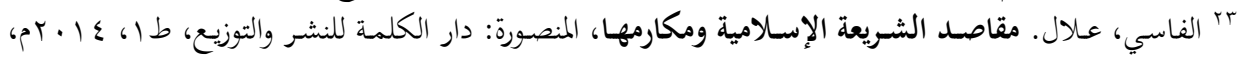


ولا شك في أنه من الخطأ المنهجي البيّن أن نتحدث عن الإبجاز العمراني الإسلامي بمنأى عن بيان مدى ارتباطه وتوجُّهه بمقصد الاستخلاف، وانضباطه بقيمه السامية.

\section{ثالثاً: الاستخلاف بوصفه حافزاً أساسياً للنفس في بناء الحضارة}

\section{1 الاستخلاف حافز أساسي لبناء الحضارة ورقيها:}

تمثل الحضارة خلاصة الممارسات الاستخلافية للكيانات البشرية المتعاقبة على وجهـ الأرض، بصرف النظر عن الزمان والماكان؛ فهي حصيلة تضافر الجهود الجماعية لأُمة ما،

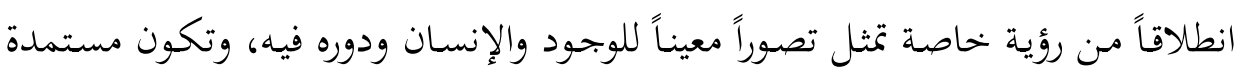
من وحي إلهي، أو اجتهاد بشري. يقول ابن عاشور: "فالخليفة آدم وخلفيته قيامه بتنفيذ

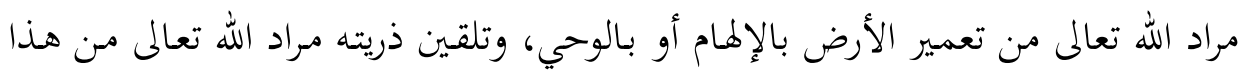

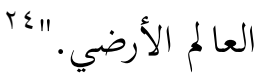

ويـدور مضسمون الرؤية الحضارية حول مبدأ مركزي تتشربه النفوس بالتربية والتنشئة

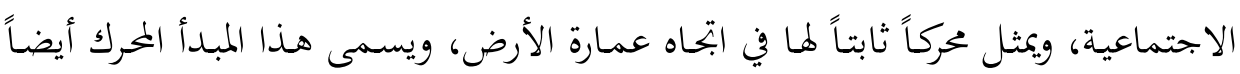
روح الحضارة.

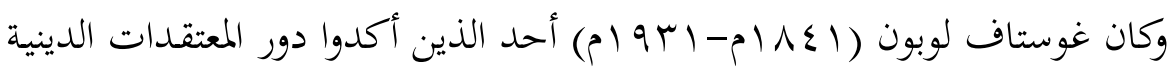

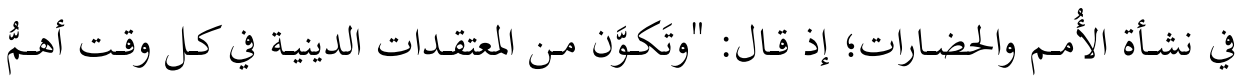

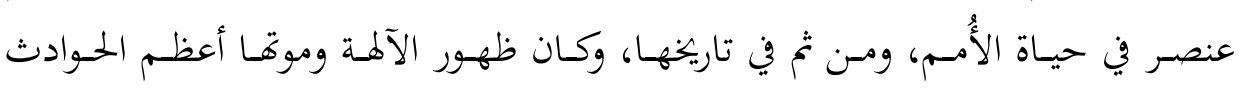

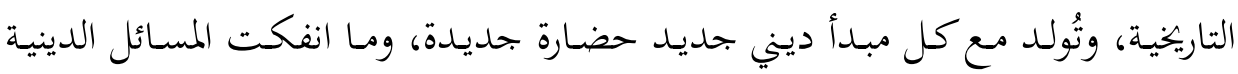

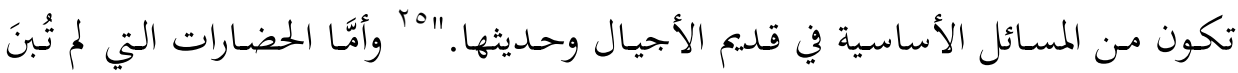
على الدين فقد بُنيت على موقف معين منه، مثل: العلمانية التي ترى فصل الدين عن

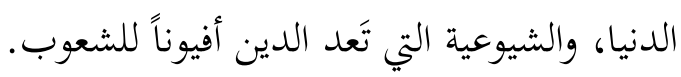

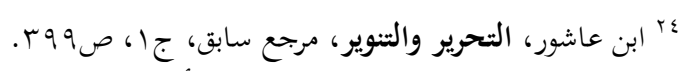

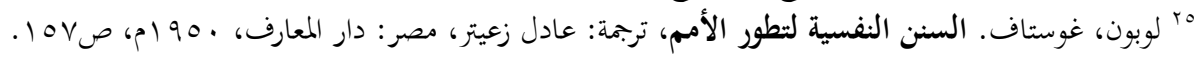


وفي هـذا السـياق، تقـوم الحضـارة الإسـلامية على أسـاس الشـريعة الإسـلامية، ومـا

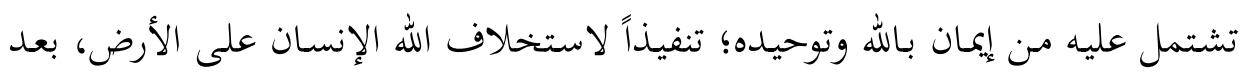
تسويته، والنفخ فيه مـن روحه، وتمكينه من اكتساب المعارف والختبرات؛ مـا جعله أهـاًا

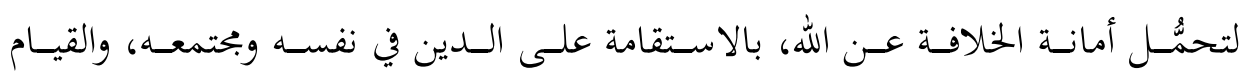

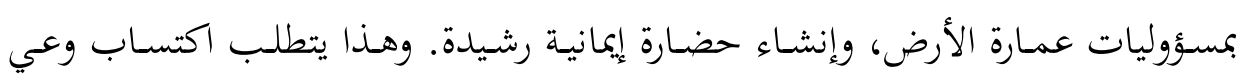

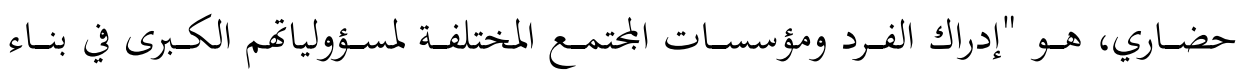
الشخصية الإنسانية المتكاملة، والسعي في دفع عملية النهضة والتقدم المعنوي والمادي من ورئ خلال إصلاح الفكر والسلوك والواقع."

فالاستتخلاف الإيمـاني يمثـل حسافزاً قويـاً لإِنسـان إلى إعمـار الأرض، بتنميـة الخـير والصلاح والهداية بين الناس، وتقليل الشر والحد من أسباب الفساد، وذلك عند تحرّكه

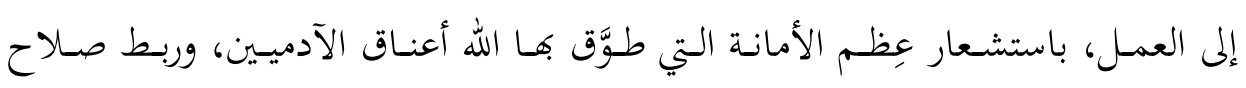
الإنسان وفلاحه وسعادته في الدنيا والآخرة بإدراك ثقلها وأساسيتها ومختلف أبعادها في

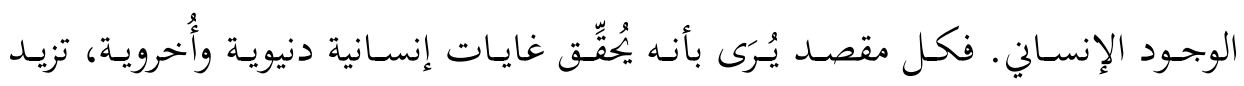

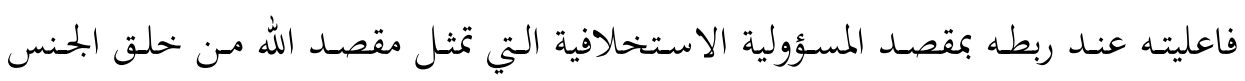

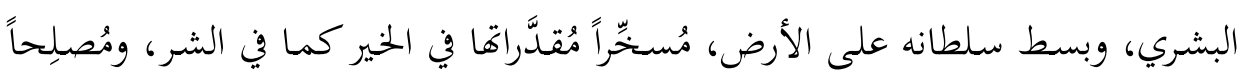
فيها أو مُفسِداً.

وهذه المسؤولية الاستخلافية تلتزم فهج الإيمان بالله وعبادته لدى المسلمين وغيرهم

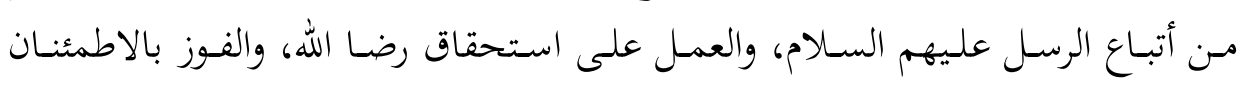

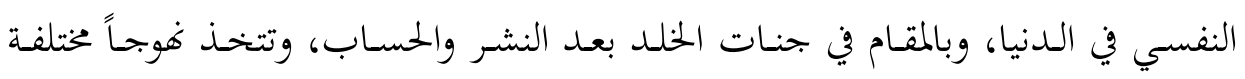
عند غير المؤمنين بالله وكتبه ورسله واليوم الآخر.

فالإيمان بالله يتحقق نتيجة الإحساس العميق بالمسؤولية بتحاه الله الخالق الرازق المحيي

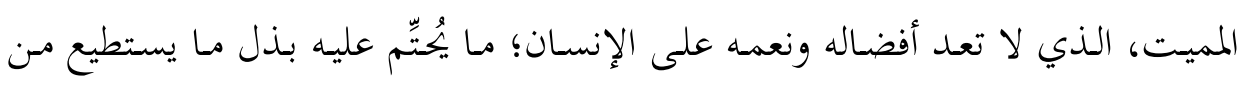
rrr القحطاني، مسفر بن علي. الوعي الحضساري: مقاربات مقاصسدية لفقه العمران الإسلامي، بيروت: الشبكة

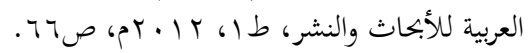


الجهاد الفكري ليتعرَّف إلى الله تعالى، ويتعلم من الوحي كيف يقوم بحقه عليه، ويدخل نفسه في سلك طاعته وعبادته مثلما أراد وشرع.

والإيمان أيضاً يجصل نتيجة استشعار الإنسان مسؤوليته بتحاه نفسه، التي إذا عرفت

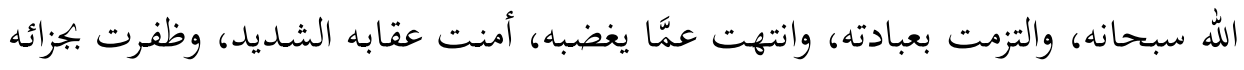

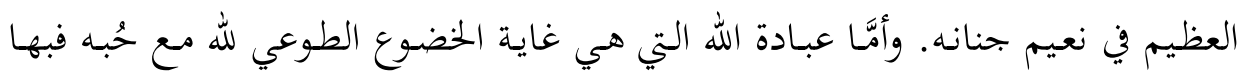

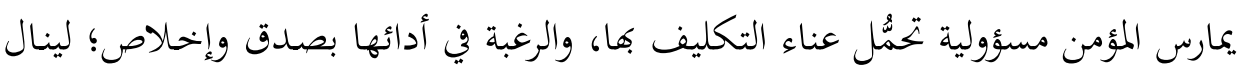
رضا الله وأجره العظيم، ويتجنب سخطه وتبعات مَن تركها أو قماون فيها. فالعبـادة إذن تأتي تنفيـذاً لمقتضـيات الإيمـان بـالله، الـذي يكـون بعـد قيـام الإنسـان

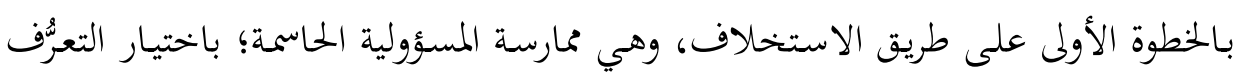

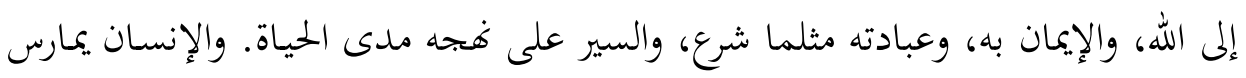

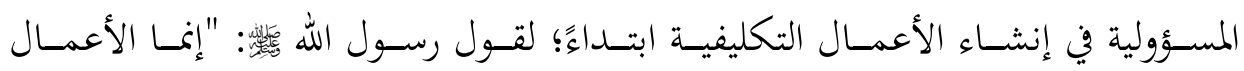

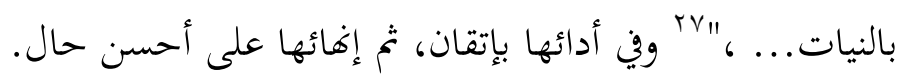
وبتحدر الإشـارة إلى أن كل أعمال الآدميين على الأرض تُقِّق المقصد الاستخلافي،

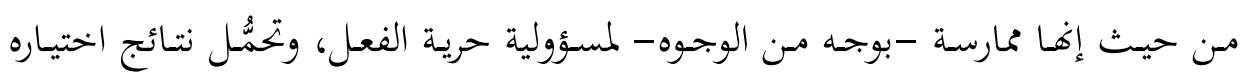
ومعاناة أدائه، وما يترتب عليه من تنعُّم أو إيلام دنيا وأُخرى.

فإذا أيقن المؤمن بصدق وعـد الله للطائعين بالجنة، ووعيده للعصاة بـالجحيم؛ فإنه

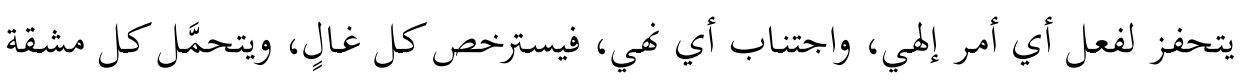

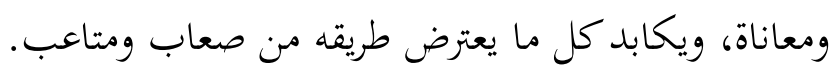

ومن هنا نتبيَّن قيمة المسؤولية التي تنشأ في النفس ضمن إطار الاستخلاف الإيماني،

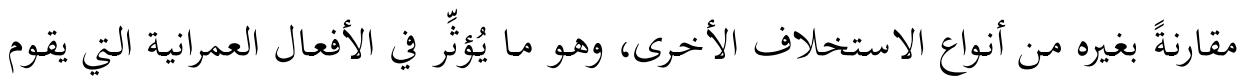

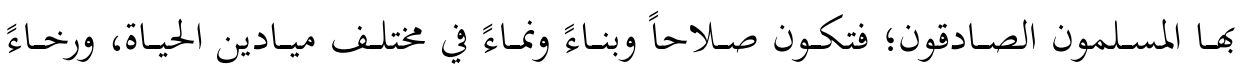

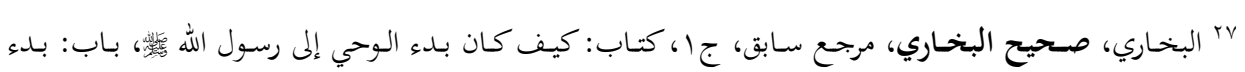

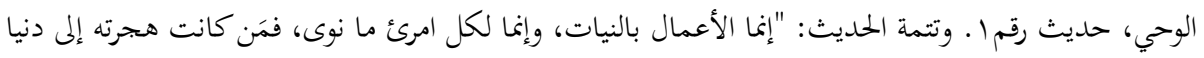

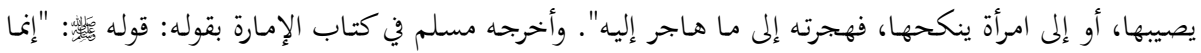




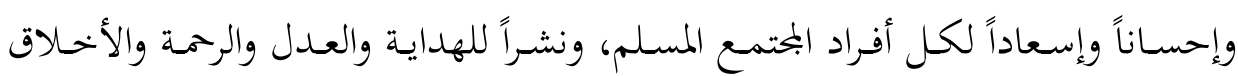

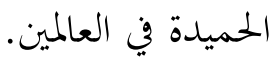

\section{r. الحضارة بوصفها ممارسة استخلافية:}

لا تقتصر الحضارة فقط على الإبحازات المادية التي تمثل المستوى الفكري والمهاري

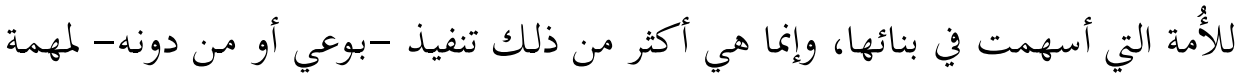

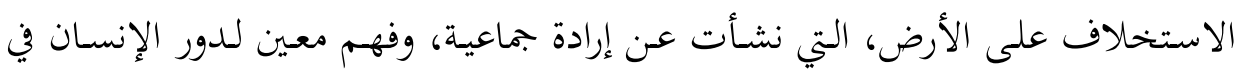

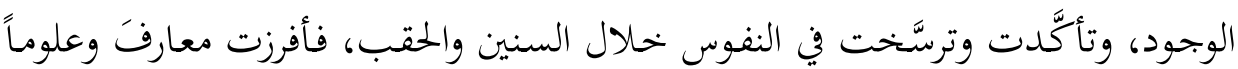

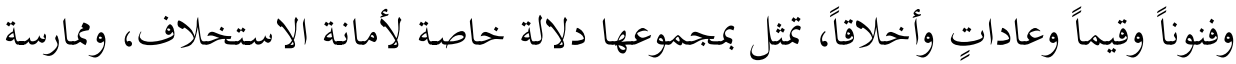
كاملة لما.

ومثلما تخضع لتأثير الأشخاص فيها، فإنم يخضعون أيضاً لتأثيراتما فيهم، ولا سيما

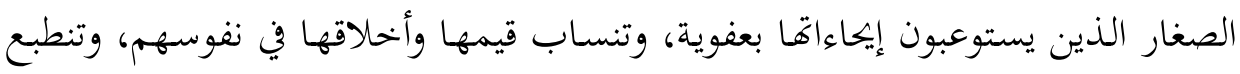

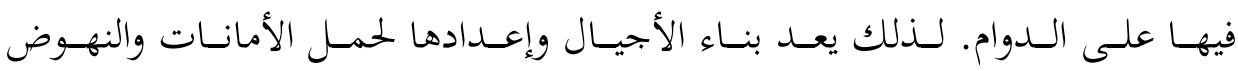

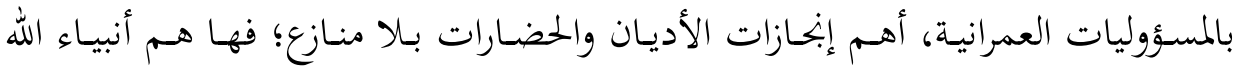

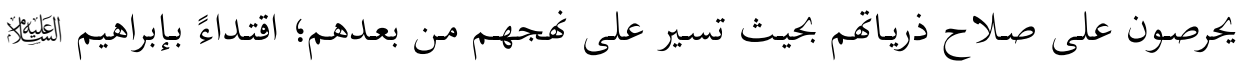

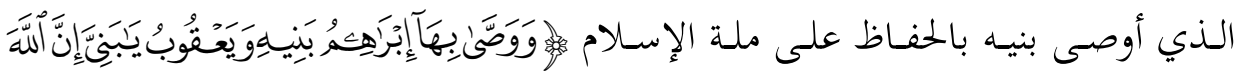

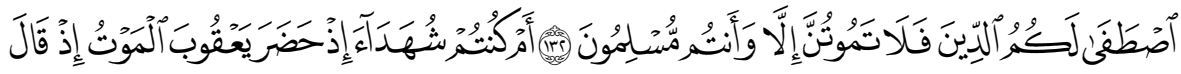

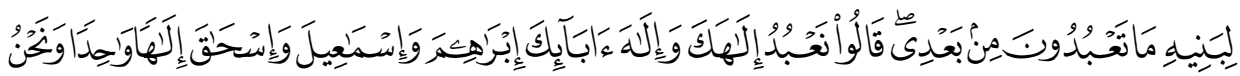

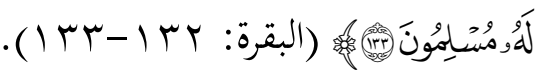

ولهذا دخلت مهمة تربية الأجيال في صُلب بعض تعريفات الحضارة، مثلما بند عند

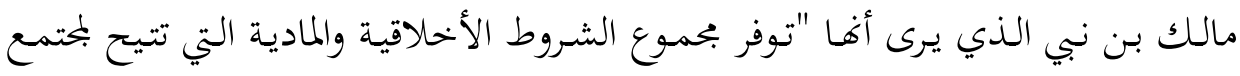

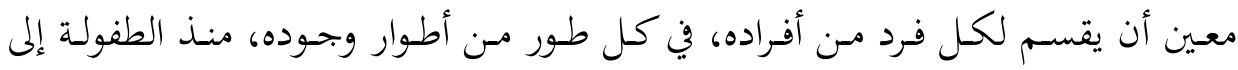

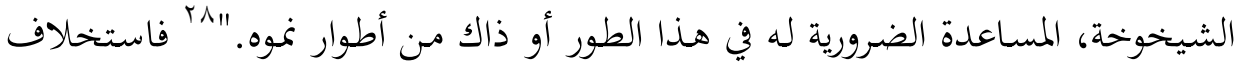

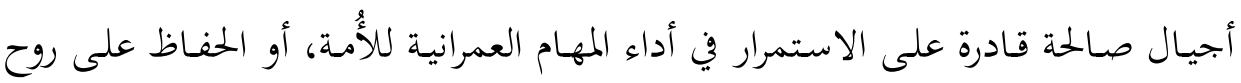

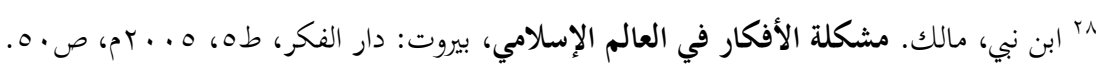


حضارتا، بل إصلاح ما فسد من رؤيتها الاستخلافية، والحيلولة دون اهتزاز أساسها في نفوسـهم؛ يعـد مـن أهـم مسؤوليات الاستخحلاف على الأرض؛ إذ أسـاس العمـران قـائم

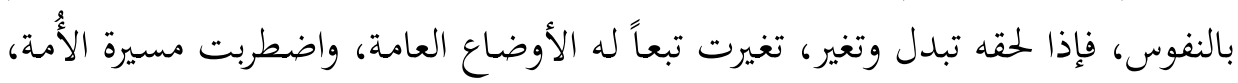

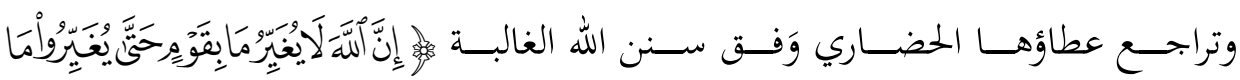

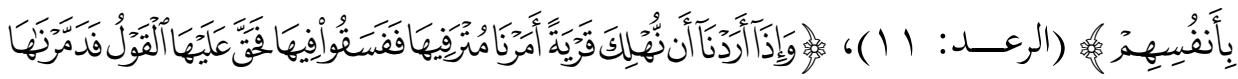

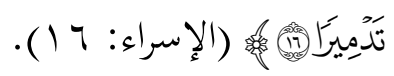

فالله تعالى استخلف الإنسـان في نفسه ودينه إلى جانب استخلافه على الأرض،

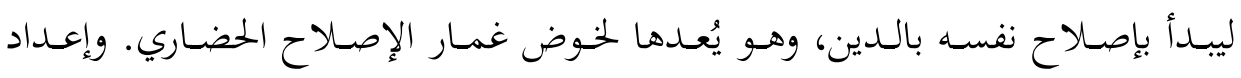

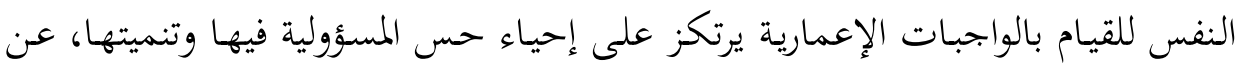

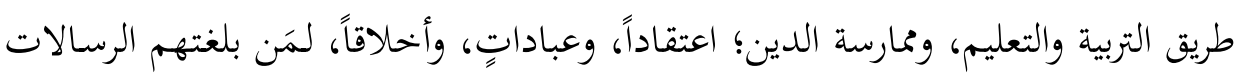

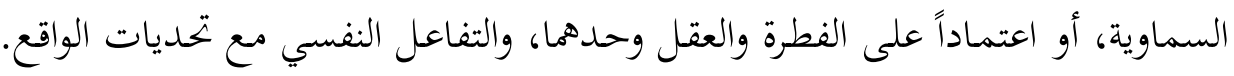

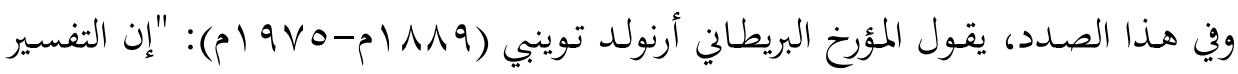

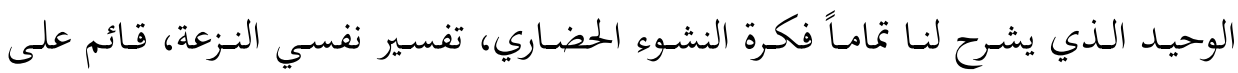

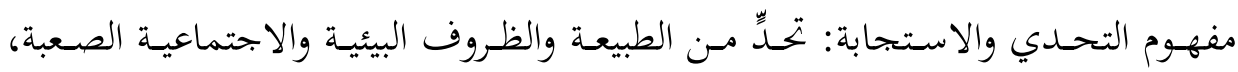

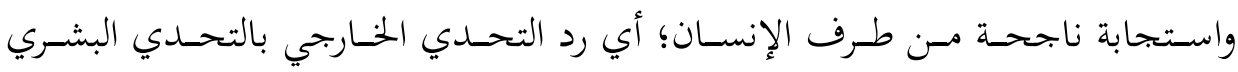

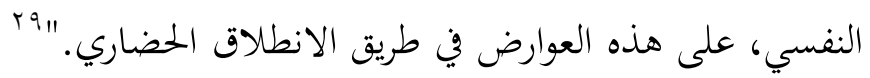

وما دام الاستخلاف الإنساني ممارسة للمسؤولية العمرانية وجميع الواجبات المتفرعة

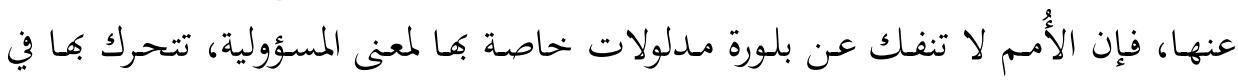

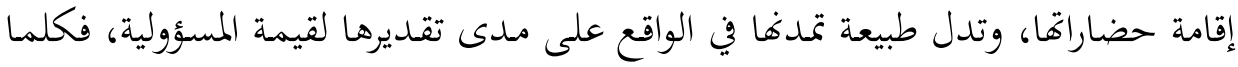

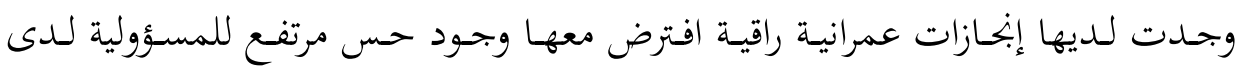

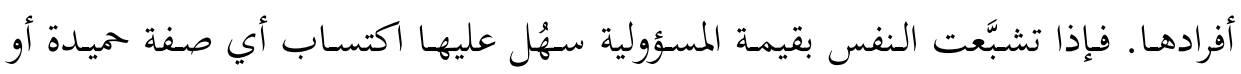

- "فلسفة التاريخ عند أرنولد توينبي"، مجلة دعوة الحق، عددر ؟، موقع وزارة الأوقاف والشؤون الإسلامية

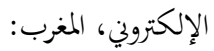

- http://www.habous.gov.ma/daouat-alhaq/item/1054. 
خلق رفيع، فغدات متصفة بحُب العمل وإتقانه، والوفـاء بالالتزامـات والعهود والعقـود،

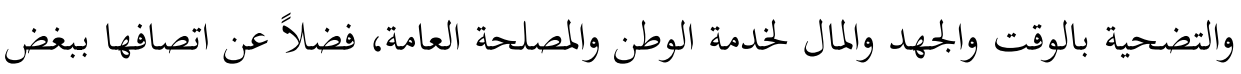
الظلم، والغش، والكذب، والزور، والقبائح كلها.

وين حال فوض الأُمة بمسؤولياتا التربوية الإصلاحية، داخل الوطن الإسلامي

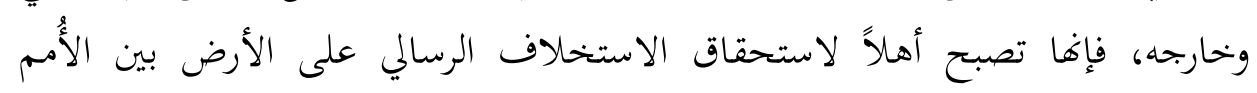

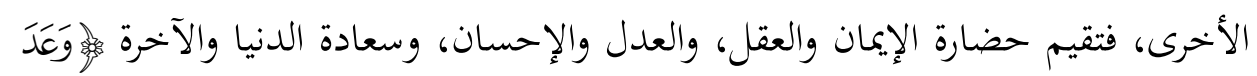

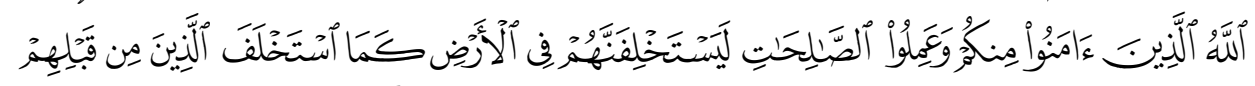

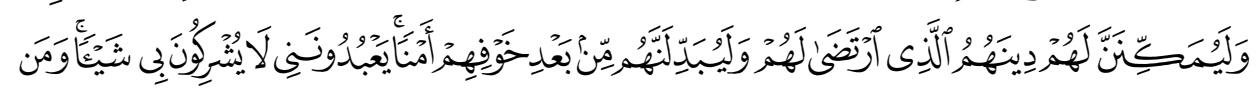

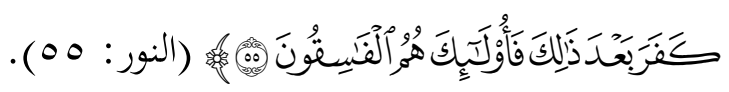

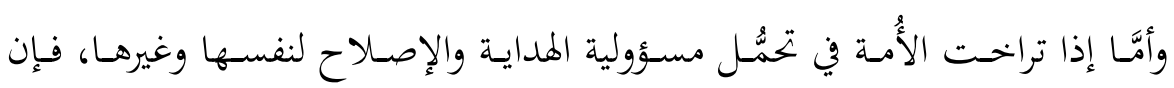
الأزمات والنكبات تتوالى عليها، وتتلاشى قوقا، وتختل أوضاعها، حتى تعود من جديد لحمل أمانة الاستخلاف الرسالي الذي هو قدرها إلى يوم الدين.

خاتمة:

هـدف البحـث إلى إبـراز إمكانيـة الانطـلاق مـن مهمـة الاسـتخلاف على الأرض

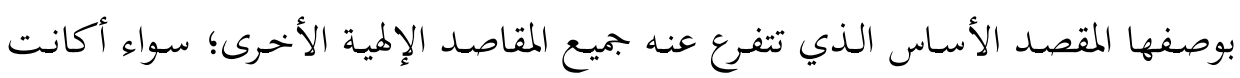

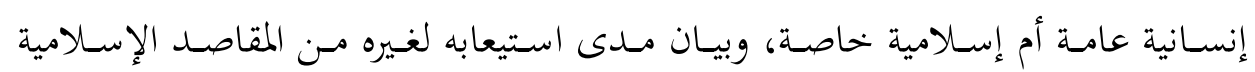

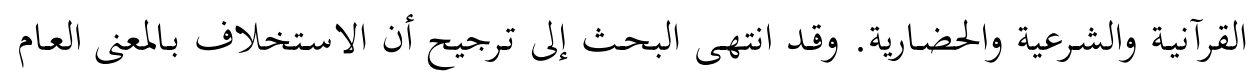

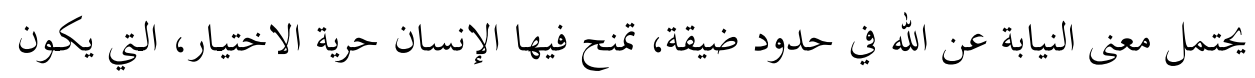

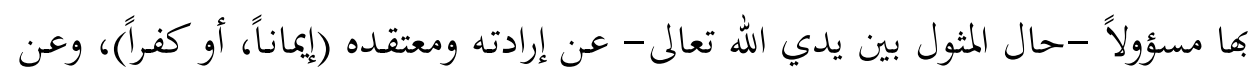
سلوكه؛ صلاحاً، وفناداً.

والاسـتخلاف بـالمعنى الخـاص هـو تكليـف واختبــار للفئـة المؤمنـة، إذا هيـأت لهـا

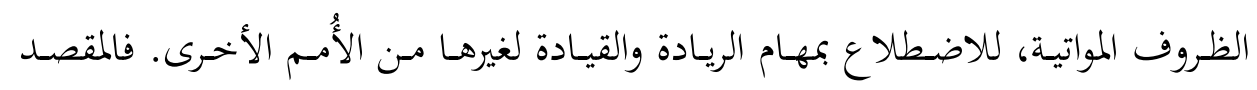

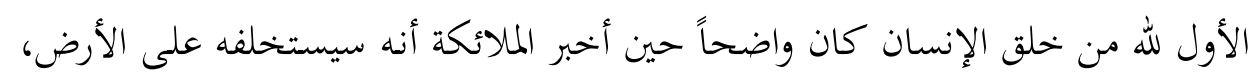




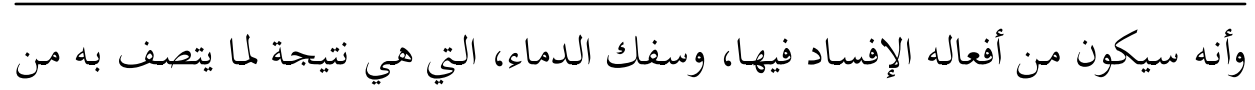

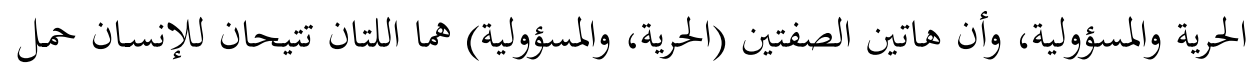

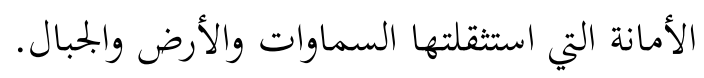

وقد خلص البحثث إلى أن مقصد استخلاف الإنسان على الأرض هو أساس كل

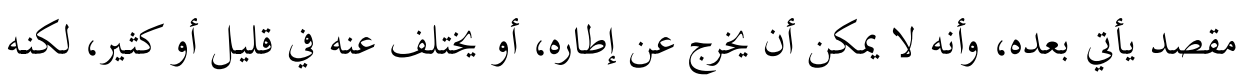

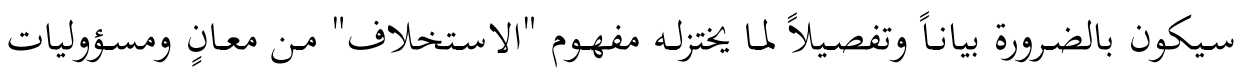

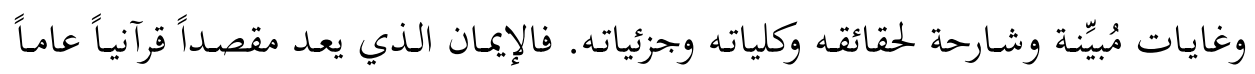

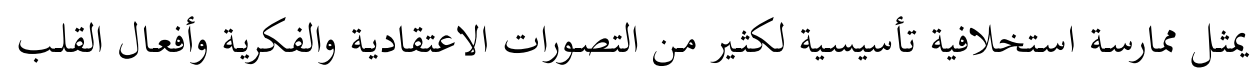

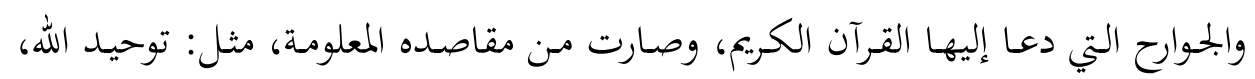

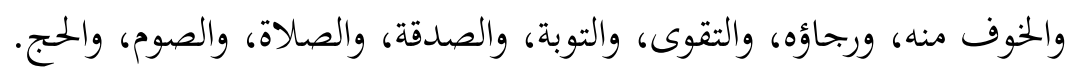
وكل هـذه المقاصـد وأمثالها تعـد امتـداداً لمقصـد الاستخحلاف، وتطبيقاً سـلوكياً له؛

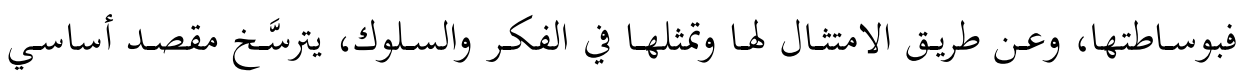

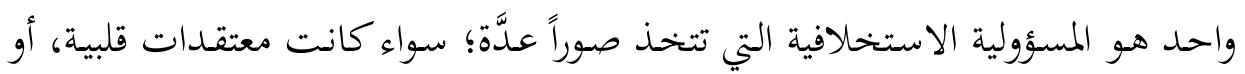
التزامات سلوكية، أو مزيجاً بينهما.

ويـرى الباحـث أن استخحلاف الله الإنسـان على الأرض يعـد أيضـاً استخلافاً لـمَن

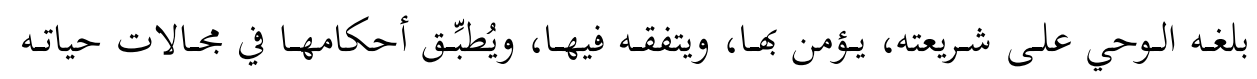

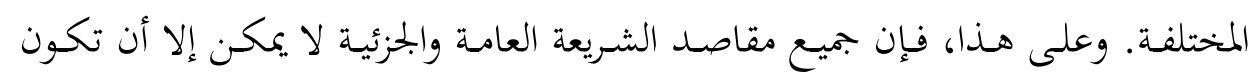
موصولة بمقصد الاستخلاف، ومؤكدة إياه في واقع التدين؛ اعتقاداً، وعبادةً، ومعاملاتٍ.

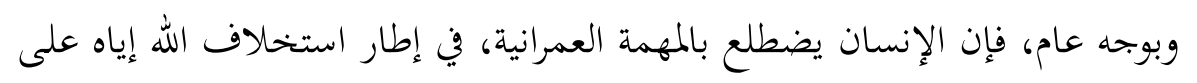

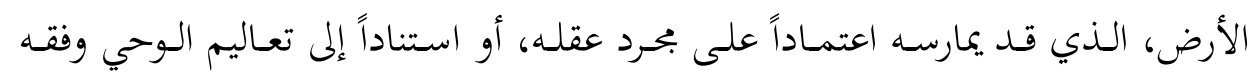

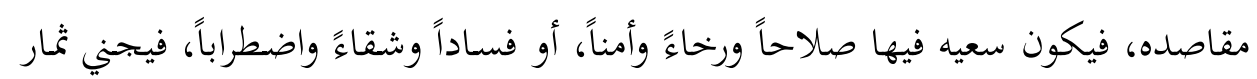
هجه العاجلة فوق الأرض، ويتعرض لحساب الله الآجل في الدار الآخرة. ختامـاً، فبإن الاستخحلاف الإيمـاني لا بُـدَّ أن يكـون حـافزاً قويـاً للمسـلم إلى إعمـار

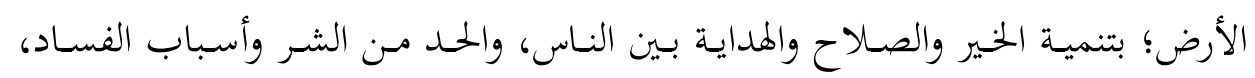




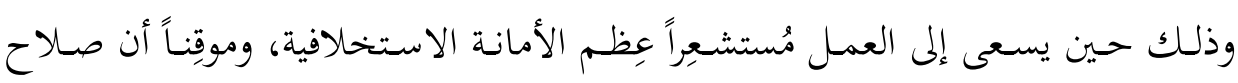

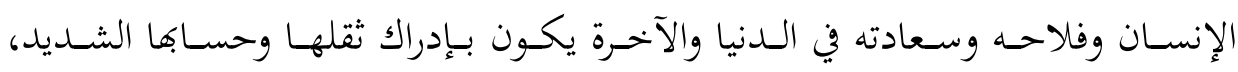

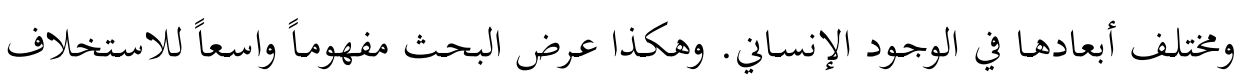

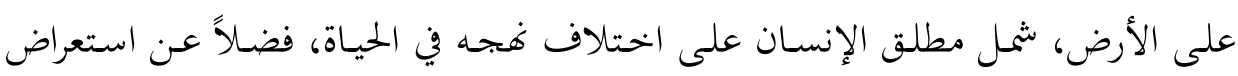

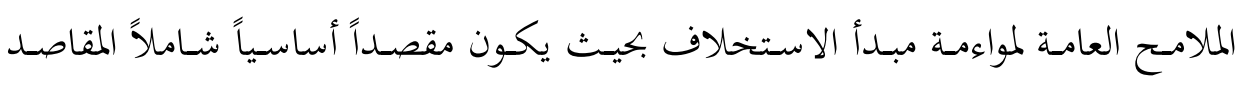

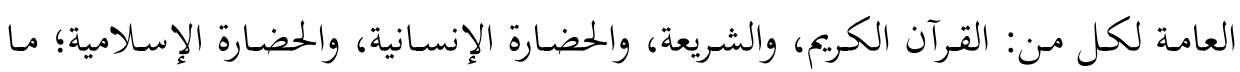

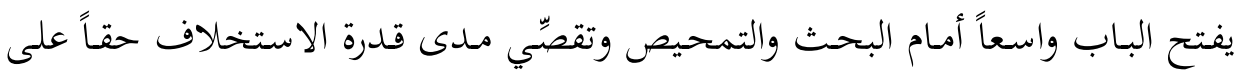

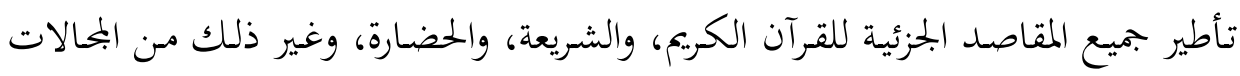

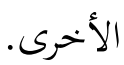

وأمَّا أهم ما يمكن استخلاصه من هذا البحث فهو استنهاض همم العلماء والباحثين

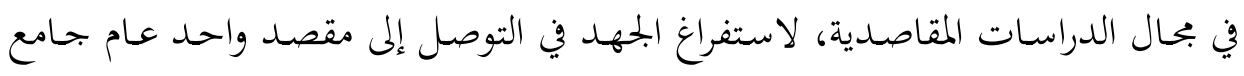

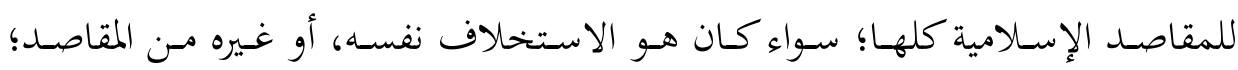

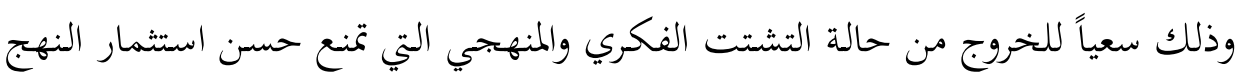

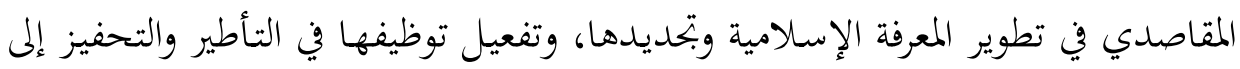
هضة فكرية حضارية رشيدة معاصرة. 